\title{
Herpetological surveys in two proposed protected areas in Liberia, West Africa
}

\author{
Mark-Oliver Rödel ${ }^{1}$, Julian Glos² \\ 1 Museum für Naturkunde - Leibniz Institute for Evolution and Biodiversity Science, Invalidenstr. 43, 10115 Berlin, Germany \\ 2 Institute for Zoology, University of Hamburg, Martin-Luther-King Platz 3, 20146 Hamburg, Germany \\ http://zoobank.org/AF7C738E-5586-490A-95AA-5D4AD4D0AA5B \\ Corresponding author: Mark-Oliver Rödel (mo.roedel@mfn.berlin)
}

\begin{abstract}
Received 17 November 2018

Accepted 14 January 2019

Published 4 February 2019

Academic editor:

Johannes Penner

\section{Key Words}

Amphibia
Anura
conservation
Crocodylia
Gymnophiona
rainforest
Sauria
Serpentes
Upper Guinea Forest

In March and April 2018 we surveyed amphibians and reptiles in two Proposed Protected Areas (PPAs) in Liberia. In the Krahn-Bassa Proposed Protected Area (KBPPA) in eastern Liberia 36 species of amphibians and 13 species of reptiles were recorded. In the Foya Proposed Protected Area (FPPA) in western Liberia 39 species of amphibians and 10 species of reptiles were recorded. The encountered herpetological communities in both sites were typical for West African rainforests. However, some species indicated disturbances, in particular at the edges of the study areas, the surrounding villages and plantations, and old artisanal gold mining sites within forests. Of particular conservation interest was the discovery of a high percentage of typical rainforest specialists with ranges restricted to the western part of the Upper Guinea rainforest biodiversity hotspot. Outstanding discoveries in KBPPA were two new species of puddle frogs, and the first country record for the arboreal, parachuting lizard Holaspis guentheri. Remarkable records in FPPA comprise a new species of stiletto snake, a new puddle frog and records of various frog species typically breeding in undisturbed rainforest streams, such as Odontobatrachus natator and Conraua alleni. Both study areas comprise an important proportion of the remaining rainforests in the Upper Guinea forest zone. The new discoveries indicate that within this biogeographic area, southeastern and western Liberian rainforest may still hold various undiscovered species and species of conservation concern. Further surveys in KBPPA and FPPA and nearby forests should clarify the distribution and conservation status of the new taxa.

This study also emphasizes that the western part of the Liberian forests comprise, at least partly, a herpetofauna which differs from that of the East of the country. The recorded threatened amphibian species are all specialized on relatively undisturbed rainforests and they all have only small geographic ranges. The remaining parts of undisturbed or little disturbed forests thus have high importance for the long-term survival of these species. In conclusion, the study areas have a high conservation potential and should be urgently protected from any further forest loss, degradation, and uncontrolled hunting.
\end{abstract}

\section{Introduction}

Amphibians and reptiles are amongst the world's most endangered organisms. Reasons are manifold, but the most important ones are unarguably habitat destruction, conversion, and fragmentation, presumably followed by pollution, disease and climate change (Stuart et al. 2004, 2008; Böhm et al. 2013). Amphibians in particular are very sensitive 
fauna is unique, and amongst the very few regions in the World where the chytrid fungus (Batrachochytrium dendrobatidis) has not yet been detected (Penner et al. 2013). However, these authors have likewise shown that many areas of presumed exceptional amphibian diversity, i.e. in Liberia, are within regions of intense logging and mining activities and not safeguarded by any protected area (Penner et al. 2019). The Krahn-Bassa Proposed Protected Area (KBPPA) in eastern Liberia and the Foya Proposed Protected Area (FPPA) in western Liberia fall within these regions of little or no official protection and predicted high amphibian diversity. However, so far no herpetological survey has targeted KBPPA and FPPA in order to verify the predictions by Penner et al. (2019). We aimed to start closing this knowledge gap by surveying some regions within the KBPPA and FPPA for amphibians. We likewise aimed to record all reptiles which we encountered. However, in particular snakes are much more difficult to observe than amphibians and we did not expect an as complete figure of species richness for reptiles as it could be expected for amphibians.

\section{Herpetological research in Liberia}

Compared to neighboring Côte d'Ivoire, the herpetofauna of Liberia is only poorly known, although herpetological specimens from Liberia have been reported as early as the beginning of the last century (Johnston 1906). The most important herpetological surveys took place in the mid-1920s to early 1940s; most notable were the expeditions of the Museum of Comparative Zoology at Harvard and the Smithsonian Institution, which resulted in the description of various new frogs and one gecko (Barbour and Loveridge 1927, 1930; Loveridge 1941). The French ichthyologist and herpetologist Paul Chabanaud surveyed mostly what is now the Republic of Guinea, but also described species from present-day Liberia (Chabanaud 1921). Likewise, the French Jean Guibé and Maxime Lamotte dealt predominantly with the fauna of the Guinean part of Mount Nimba, but included Liberian material in their papers (Guibé and Lamotte 1958a, 1963). From the Liberian part of Mount Nimba a second species of viviparous toad, Nimbaphynoides liberiensis, was described (Xavier 1978), which was, however, later synonymized with the Guinean populations (Sandberger et al. 2010). Further Liberian records and new species were published by Parker (1936) and Taylor and Weyer (1958). Some amphibian species have been also made known through the work of parasitologists (e.g. Euzet et al. 1969). An important boost to the discovery of West African amphibians in general, and treefrogs in particular, was due to the work of the Belgian Raymond Laurent and the Dane Arne Schiøtz. The latter also worked and collected in Liberia (e.g. Laurent 1958; Schiøtz 1967, 1968).

These early discoveries were followed by a longer period without any herpetological data from Liberia. Liberia was always hard to access due to the lack of infrastructure such as roads in most parts of the country, but from 1989-2003 a particularly brutal civil war stopped all scientific exploration within the country. Only in 2005, on a Rapid Assessment organized by Conservation International, Annika Hillers surveyed amphibians and reptiles in three Liberian forests, reporting five frog species new for the country (Hillers and Rödel 2007). More recently Rödel et al. (2009a, 2010) described two new frog species from the Liberian part of Mount Nimba, one of which was later also recorded in the more southern Putu Range by Nopper et al. (2012). In recent years many surveys in various Liberian regions were undertaken by numerous researchers, usually working as consultants for logging and mining explorations. Unfortunately, none of these results have been so far made publicly available.

\section{Material and methods}

\section{Study sites, study periods and sampling effort}

Both study areas were surveyed during the beginning of the rainy season. The Krahn-Bassa Proposed Protected Area (KBPPA) is located in southeastern Liberia, across the Grand Gedeh, River Cess and Sinoe counties. The nearest larger town is Zwedru. KBPPA comprises 290,167 ha within the larger Krahn-Bassa National Forest (WCF \& FDA 2017). We surveyed KBPPA on 23-26 March 2018 (Camp 1, in the north of the area; 06 02'39.9"N, 008 20'03.6"W) and 28-31 March 2018 (Camp 2, in the central-eastern part of the area; $05^{\circ} 39^{\prime} 02.1^{\prime \prime} \mathrm{N}$, $\left.008^{\circ} 39^{\prime} 05.0^{\prime \prime} \mathrm{W}\right)$. KBPPA is part of Liberia's two remaining forest blocks, the Taï-Grebo-Sapo forest complex (Taï being the largest remaining rainforest in neighboring Côte d'Ivoire). It consists of primary forest with high canopy cover, although the edges of the forest are partly heavily degraded by logging and agricultural encroachment. Most prominent signs of human activities in the core forest area were former artisanal gold mining pits and up to an average of one cartridge per $100 \mathrm{~m}$, indicating a very high hunting pressure. Both camps were near a larger river. The surrounding forest was in good shape and comprised slightly undulating hilly areas with drier parts of high canopy forest, swampy areas in the valley and some smaller streams on sandy and rocky ground. In total we invested 142 person/hours (four persons working simultaneously) searching for amphibians and reptiles (Table 1).

The Foya Proposed Protected Area (FPPA) in western Liberia is the extension of the remaining block of the Gola Rainforest National Park in Sierra Leone and the Gola Forest National Park in Liberia. We surveyed areas in the north of FPPA on 4-6 April 2018 (Camp 1, ca $3 \mathrm{~km}$ south of Ducorbond; $\left.08^{\circ} 00^{\prime} 46.0^{\prime \prime} \mathrm{N}, 010^{\circ} 25^{\prime} 32.1^{\prime \prime} \mathrm{W}\right)$ and 7-9 April 2018 (Ducorbond village; 0802'37.9"N, 010²4'35.1"W). The forest is still partly primary (Fig. 1b) but was affected by logging since the 1980s. Huge areas around villages and along a road connecting to the Sierra Leonean border are cleared from forest and turned into agricultural land (Fig. 1d), i.e. swamps into rice paddies. The forest still maintains 


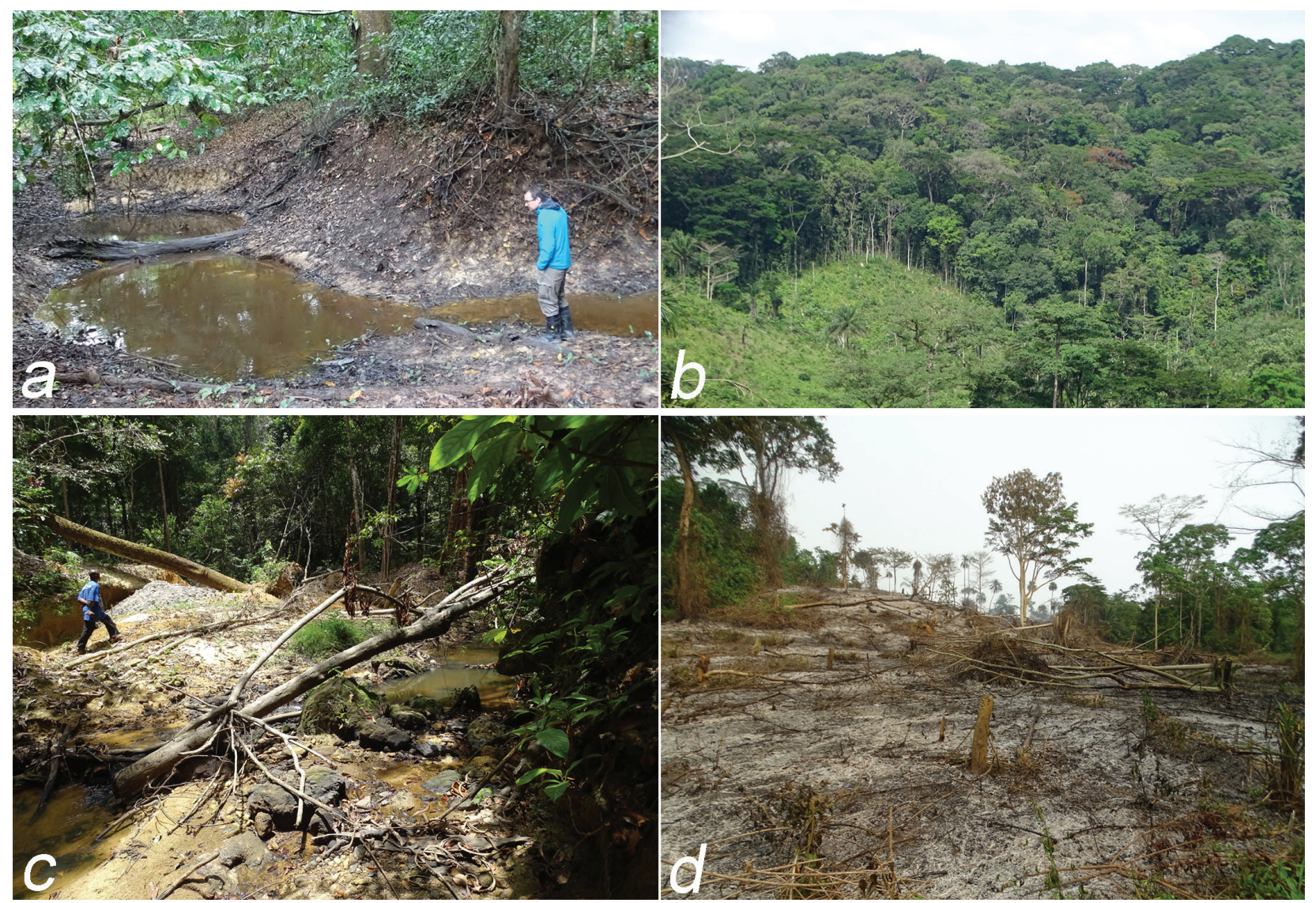

Figure 1. Natural and disturbed habitats in the Krahn-Bassa (KBPPA) and Foya Proposed Protected Areas (FPPA). a Remaining puddles of a stream in Krahn-Bassa, habitat of Aubria subsigillata, Amnirana 'albolabris West', Leptopelis macrotis, Hyperolius chlorosteus and Chiromantis rufescens. b View on a near primary forest patch in FPPA. c Artisanal gold mining area near a small forest stream in FPPA, frogs breeding in these puddles were Xenopus tropicalis, Sclerophrys maculata, Hyperolius picturatus, Phlyctimantis boulengeri, Ptychadena longirostris, P. sp., and Chiromantis rufescens. d Recently slash and burn cleared forest patch in FPPA, prepared for establishing a cacao plantation.

high canopy cover and a high proportion of timber trees (SCNL 2017), however, traces of extraction of single, high value timber trees, as well as vast areas of artisanal gold mining were frequently found in various places (Fig. 1c). Most of the terrain is hilly, and in part, with steep slopes. Small to larger forest streams are present, some with torrent water and large boulders. Signs of hunting were present, but to a much lower degree than in FPPA. In total we invested 115 person/hours (four persons working simultaneously) searching for amphibians and reptiles in FPPA (Table 1).

\section{Field work and vouchers}

Amphibians and reptiles were recorded during visual and acoustic encounter surveys by four people. The surveys were undertaken during day and night. Searching techniques included visual scanning of the terrain and investigation of potential hiding places or very specific habitats (e.g. tree holes, small rivers, and waterfalls); for tadpoles we searched by dip-netting in all available potential breeding sites (Heyer et al. 1994; Rödel and Ernst 2004).

Our sampling design only provided qualitative and semi-quantitative data. We therefore calculated the es- timated species richness and, hence, our sampling efficiency with the Jackknife 1 and Chao 2 estimators using EstimateS (Collwell 2005). These incidence based estimators were calculated based on the amphibian presence/ absence data of discrete survey units. These units consisted of surveys of 1.5-4 h each, by four people, in different parts of the two areas, assuming that sampling effort of survey units were comparable. To visualize species accumulation as a relation of sampling effort, and to avoid order effects, we calculated sample-based rarefaction curves of amphibian species richness (999 permutations) using Past2.17 (Hammer et al. 2001).

The nomenclature for amphibians follows Frost (2018), and for reptiles we follow Uetz (2018). Vouchers were euthanized by either placing animals in a chlorobutanol solution (amphibians) or by putting some benzocaine paste (reptiles) in the mouth. After death, tissue samples (liver) were taken and preserved in 95\% ethanol, the animals were injected with $75 \%$ ethanol. Voucher specimens and tissue samples are deposited in the zoological collection of the Museum für Naturkunde - Leibniz Institute for Evolution and Biodiversity Science, Berlin (ZMB). 
Table 1. Details on study sites in the Krahn-Bassa (KBPPA) and Foya (FPPA) herpetological survey 2018. "Person/hours" calculated as time surveyed $\times$ four persons, geographic coordinates refer to initial points of survey transects.

\begin{tabular}{|c|c|c|c|c|c|c|}
\hline Area & Date & $\begin{array}{c}\text { Time of } \\
\text { day }\end{array}$ & $\begin{array}{c}\text { Person/ } \\
\text { hours }\end{array}$ & Site details & latitude $(\mathrm{N})$ & longitude (W) \\
\hline KBPPA & 24.03 .18 & morning & 08:00 & Closed forest parallel to small stream & $06^{\circ} 02^{\prime} 39.9^{\prime \prime}$ & $008^{\circ} 20^{\prime} 09.6^{\prime \prime}$ \\
\hline KBPPA & 24.03 .18 & afternoon & $13: 00$ & Closed forest parallel to small stream & $06^{\circ} 02^{\prime} 39.9^{\prime \prime}$ & $008^{\circ} 20^{\prime} 09.6^{\prime \prime}$ \\
\hline KBPPA & 24.03 .18 & night & 08:00 & Closed forest & $06^{\circ} 02^{\prime} 39.9^{\prime \prime}$ & $008^{\circ} 20^{\prime} 09.6^{\prime \prime}$ \\
\hline KBPPA & 25.03 .18 & morning & $15: 00$ & Closed forest & $06^{\circ} 02^{\prime} 34.8^{\prime \prime}$ & $008^{\circ} 20^{\prime} 10.3^{\prime \prime}$ \\
\hline KBPPA & 25.03 .18 & night & 08:00 & Closed forest & $06^{\circ} 02^{\prime} 34.8^{\prime \prime}$ & $008^{\circ} 20^{\prime} 10.3^{\prime \prime}$ \\
\hline KBPPA & 26.03 .18 & afternoon & $08: 40$ & Closed forest parallel to small stream & $06^{\circ} 02^{\prime} 34.8^{\prime \prime}$ & $008^{\circ} 20^{\prime} 10.3^{\prime \prime}$ \\
\hline KBPPA & 26.03 .18 & night & 07:00 & Closed forest & $06^{\circ} 02^{\prime} 34.8^{\prime \prime}$ & $008^{\circ} 20^{\prime} 10.3^{\prime \prime}$ \\
\hline KBPPA & 28.03 .18 & night & 07:00 & Closed forest parallel to large river & $05^{\circ} 39^{\prime} 02.1^{\prime \prime}$ & $008^{\circ} 39^{\prime} 05.0^{\prime \prime}$ \\
\hline KBPPA & 29.03 .18 & morning & $16: 00$ & Closed forest parallel to large river & $05^{\circ} 39^{\prime} 02.1^{\prime \prime}$ & $008^{\circ} 39^{\prime} 05.0^{\prime \prime}$ \\
\hline KBPPA & 29.03 .18 & night & $11: 40$ & Closed forest & $05^{\circ} 39^{\prime} 02.1^{\prime \prime}$ & $008^{\circ} 39^{\prime} 05.0^{\prime \prime}$ \\
\hline KBPPA & 30.03 .18 & afternoon & $10: 00$ & Closed forest & $05^{\circ} 39^{\prime} 02.1^{\prime \prime}$ & $008^{\circ} 39^{\prime} 05.0^{\prime \prime}$ \\
\hline KBPPA & 30.03 .18 & night & 09:00 & Closed forest and gold mining pits & $05^{\circ} 39^{\prime} 02.1^{\prime \prime}$ & $008^{\circ} 39^{\prime} 05.0^{\prime \prime}$ \\
\hline KBPPA & 31.03 .18 & morning & $16: 00$ & Closed forest parallel to large river & $05^{\circ} 39^{\prime} 02.1^{\prime \prime}$ & $008^{\circ} 39^{\prime} 05.0^{\prime \prime}$ \\
\hline KBPPA & 31.03 .18 & night & 04:00 & Closed forest and gold mining pits & $05^{\circ} 39^{\prime} 02.1^{\prime \prime}$ & $008^{\circ} 39^{\prime} 05.0^{\prime \prime}$ \\
\hline FPPA & 04.04 .18 & night & 08:00 & Closed forest along small stream & $08^{\circ} 00^{\prime} 46.0^{\prime \prime}$ & $010^{\circ} 25^{\prime} 32.1^{\prime \prime}$ \\
\hline FPPA & 05.04 .18 & morning & $14: 00$ & Closed forest & $08^{\circ} 00^{\prime} 46.0^{\prime \prime}$ & $010^{\circ} 25^{\prime} 32.1^{\prime \prime}$ \\
\hline FPPA & 05.04 .18 & night & $14: 00$ & Closed forest & $08^{\circ} 00^{\prime} 21.3^{\prime \prime}$ & $010^{\circ} 25^{\prime} 20.2^{\prime \prime}$ \\
\hline FPPA & 06.04 .18 & morning & 19:00 & Closed forest along small and large streams, including cascades & $08^{\circ} 01^{\prime} 16.2^{\prime \prime}$ & $010^{\circ} 25^{\prime} 31.4^{\prime \prime}$ \\
\hline FPPA & 06.04 .18 & night & $12: 00$ & Closed forest along small and large streams, including cascades & $08^{\circ} 01^{\prime} 16.2^{\prime \prime}$ & $010^{\circ} 25^{\prime} 31.4^{\prime \prime}$ \\
\hline FPPA & 07.04 .18 & night & 07:00 & Along road and cocoa plantations & $08^{\circ} 02^{\prime} 37.9^{\prime \prime}$ & $010^{\circ} 24^{\prime} 35.1^{\prime \prime}$ \\
\hline FPPA & 08.04 .18 & morning & $18: 00$ & Closed forest, along stream including cascades & $08^{\circ} 03^{\prime} 18.6^{\prime \prime}$ & $010^{\circ} 23^{\prime} 04.0^{\prime \prime}$ \\
\hline FPPA & 08.04 .18 & night & 08:00 & Closed forest, along stream including cascades & $08^{\circ} 03^{\prime} 18.6^{\prime \prime}$ & $010^{\circ} 23^{\prime} 04.0^{\prime \prime}$ \\
\hline FPPA & 09.04 .18 & morning & $10: 00$ & Closed forest and along streams & $08^{\circ} 03^{\prime} 02.5^{\prime \prime}$ & $010^{\circ} 23^{\prime} 15.9^{\prime \prime}$ \\
\hline FPPA & 09.04 .18 & night & 05:20 & Closed forest and along streams & $08^{\circ} 03^{\prime} 02.5^{\prime \prime}$ & $010^{\circ} 23^{\prime} 15.9^{\prime \prime}$ \\
\hline
\end{tabular}

\section{Results}

\section{Commented species list}

Numbers listed in brackets after study site abbreviations refer to voucher specimens (ZMB) and tissue (ZMB or $\mathrm{RG}$ numbers; $\mathrm{RG}=$ tissue only) accessioned in $\mathrm{ZMB}$. In Table 2 we provide a summary of all species recorded in Krahn-Bassa Proposed Protected Area (KBPPA) and in Foya Proposed Protected Area (FPPA) with their preferred habitat, range, and IUCN Red List status.

\section{Amphibia \\ Gymnophiona \\ Dermophiidae}

\section{Geotrypetes cf. seraphini (Duméril, 1859); KBPPA (ZMB 88492)}

Three Geotrypetes species are known from West Africa (Taylor 1968), which can be mainly distinguished by the number of primary and secondary annuli (body rings). The most common species is Geotrypetes seraphini, ranging from Sierra Leone to western Central Africa (Taylor 1968; Frost 2018). The fossorial amphibians are usually found in swampy areas of the rainforest zone. We detected one specimen (bluish purple) in KBPPA at night, near the second camp below a stone, in a swampy zone with small creeks which were heavily disturbed by previous artisanal gold mining. Unfortunately, it managed to escape into the ground. A second, greyer and larger individual was found dead in the leaf litter close to a river (Fig. 2a). As its hind part was apparently eaten by a predator, annuli counts were not possible in either specimens.

\section{Anura \\ Pipidae}

\section{Xenopus tropicalis (Gray, 1864); KBPPA (ZMB 88454, 88466); FPPA (ZMB 88504)}

An aquatic species of forests, degraded forests, and gallery forests in the moist savanna zone, which can be found from Senegal to western Cameroon (Rödel 2000). Both adults and tadpoles were often found in natural waters but also in small water-filled pits resulting from gold mining.

\section{Arthroleptidae}

Arthroleptis sp. 1 \& 2; KBPPA (ZMB 88476, 88477); FFPA (no voucher)

Both direct developing species occur in forest (Ernst and Rödel 2005, 2006). While Arthroleptis sp. 1 tolerates degraded forest, $A$. sp. 2 usually only lives in primary forest. Call and calling sites between both taxa are distinctly different. Males of Arthroleptis sp. 1 have a typical insect-like longer trill call, are well concealed within low and dense vegetation, and are usually easy to detect but hard to catch. In contrast, males of $A$. sp. 2 have very 
Table 2. Amphibian species recorded in Krahn-Bassa Proposed Protected Area (KBPPA) in eastern Liberia and Foya Proposed Protected Area (FPPA) in western Liberia (in alphabetic order) with preferred habitat, distribution and IUCN Red List category; \# $=$ number of records per site (number of individuals was usually much higher); $\mathrm{pf}=$ primary forest; $\mathrm{df}=$ degraded forest; oh $=\mathrm{open}$ habitat; wUG = western Upper Guinea; UG = Upper Guinea; wA = western Africa; A = Africa (any range beyond western Africa); ? = range not known; $\mathrm{LC}=$ Least Concern; NT = Near Threatened; VU = Vulnerable; NE = not evaluated.

\begin{tabular}{|c|c|c|c|c|c|c|c|c|c|c|c|}
\hline Genus & Species & \# KBPPA & \# FPPA & pf & df & oh & wUG & UG & wA & A & IUCN \\
\hline \multirow[t]{3}{*}{ Afrixalus } & dorsalis & & 5 & & 1 & 1 & & & 1 & & LC \\
\hline & fulvovittatus & & 2 & & 1 & & & & 1 & & LC \\
\hline & nigeriensis & 5 & 1 & 1 & & & & 1 & & & LC \\
\hline \multirow[t]{2}{*}{ Amnirana } & 'albolabris West' & 7 & 6 & 1 & 1 & & & 1 & & & $\mathrm{NE}$ \\
\hline & occidentalis & & 1 & 1 & & & & 1 & & & EN \\
\hline \multirow[t]{2}{*}{ Arthroleptis } & sp. 1 & 8 & 3 & 1 & 1 & & 1 & & & & $\mathrm{NE}$ \\
\hline & sp. 2 & 4 & 3 & 1 & & & 1 & & & & $\mathrm{NE}$ \\
\hline Astylosternus & occidentalis & 2 & 4 & 1 & & & 1 & & & & LC \\
\hline Aubria & subsigillata & 1 & & 1 & 1 & & & & 1 & & LC \\
\hline Cardioglossa & occidentalis & 5 & 5 & 1 & & & & 1 & & & $\mathrm{NE}$ \\
\hline Chiromantis & rufescens & 6 & 3 & 1 & & & & & 1 & & LC \\
\hline Conraua & alleni & 2 & 6 & 1 & & & 1 & & & & VU \\
\hline Geotrypetes & seraphini & 2 & & 1 & 1 & & & & 1 & & LC \\
\hline Hoplobatrachus & occipitalis & & 2 & & 1 & 1 & & & & 1 & LC \\
\hline \multirow[t]{7}{*}{ Hyperolius } & chlorosteus & 9 & 6 & 1 & & & 1 & & & & NT \\
\hline & concolor & 1 & 2 & & 1 & 1 & & & 1 & & LC \\
\hline & fusciventris & 3 & & & 1 & & & & 1 & & LC \\
\hline & guttullatus & 1 & 3 & & 1 & 1 & & & 1 & & LC \\
\hline & picturatus & 7 & 2 & 1 & & & 1 & & & & LC \\
\hline & soror & & 1 & 1 & & & 1 & & & & DD \\
\hline & zonatus & 1 & 1 & 1 & & & 1 & & & & NT \\
\hline \multirow[t]{4}{*}{ Leptopelis } & macrotis & 6 & 6 & 1 & & & & 1 & & & NT \\
\hline & occidentalis & 3 & 1 & 1 & & & & 1 & & & NT \\
\hline & spiritusnoctis & 7 & 6 & 1 & 1 & & & 1 & & & LC \\
\hline & viridis & & 3 & & & 1 & & & 1 & & $\mathrm{LC}$ \\
\hline Odontobatrachus & natator & & 3 & 1 & & & 1 & & & & NT \\
\hline Phlyctimantis & boulengeri & & 3 & & 1 & & & & 1 & & $\mathrm{LC}$ \\
\hline \multirow[t]{14}{*}{ Phrynobatrachus } & alleni & 7 & 4 & 1 & & & & 1 & & & NT \\
\hline & 'aff. alleni' & 2 & & 1 & & & $?$ & & & & $\mathrm{NE}$ \\
\hline & calcaratus & 1 & & & 1 & 1 & & & 1 & & LC \\
\hline & fraterculus & & 1 & & 1 & & 1 & & & & LC \\
\hline & guineensis & 2 & & 1 & & & 1 & & & & NT \\
\hline & gutturosus & 3 & & 1 & 1 & 1 & & 1 & & & LC \\
\hline & ,sp. gutturosus/tokba‘ & 3 & & 1 & & & $?$ & & & & $\mathrm{NE}$ \\
\hline & latifrons & & 1 & & 1 & 1 & & & 1 & & LC \\
\hline & liberiensis & 7 & 5 & 1 & & & & 1 & & & NT \\
\hline & phyllophilus & 1 & 1 & 1 & & & 1 & & & & NT \\
\hline & plicatus & 8 & & 1 & & & & 1 & & & LC \\
\hline & 'sp. Gola' & & 2 & 1 & & & 1 & & & & $\mathrm{NE}$ \\
\hline & tokba & 7 & 5 & 1 & 1 & & 1 & & & & LC \\
\hline & villiersi & 2 & & 1 & & & 1 & & & & VU \\
\hline \multirow[t]{5}{*}{ Ptychadena } & aff. aequiplicata & 6 & 1 & & & & 1 & & & & $\mathrm{NE}$ \\
\hline & cf. bibroni & 1 & 3 & & 1 & 1 & & & & 1 & LC \\
\hline & longirostris & 1 & 3 & 1 & 1 & & & 1 & & & LC \\
\hline & mascareniensis & & 1 & & & 1 & & & & 1 & LC \\
\hline & sp. & & 6 & & 1 & & $?$ & & & & $\mathrm{NE}$ \\
\hline \multirow[t]{2}{*}{ Sclerophrys } & maculata & 1 & 3 & & 1 & 1 & & & & 1 & LC \\
\hline & togoensis & 2 & 2 & 1 & & & & 1 & & & NT \\
\hline Xenopus & tropicalis & 2 & 4 & 1 & 1 & & & & 1 & & LC \\
\hline 49 species & total & 136 & 120 & 33 & 22 & 11 & 16 & 13 & 13 & 4 & \\
\hline
\end{tabular}

short and high-pitched, katydid-like calls. The calls usually sound as if they are coming from the canopy, and the frogs are extremely difficult to localize, although the males call fully exposed from the forest floor (M.-O.
Rödel pers. obs.). Currently it is not possible to assign a valid scientific name to either of these species, as the taxonomy of this genus is not yet clarified (compare Rödel and Bangoura 2004; Blackburn 2010). 

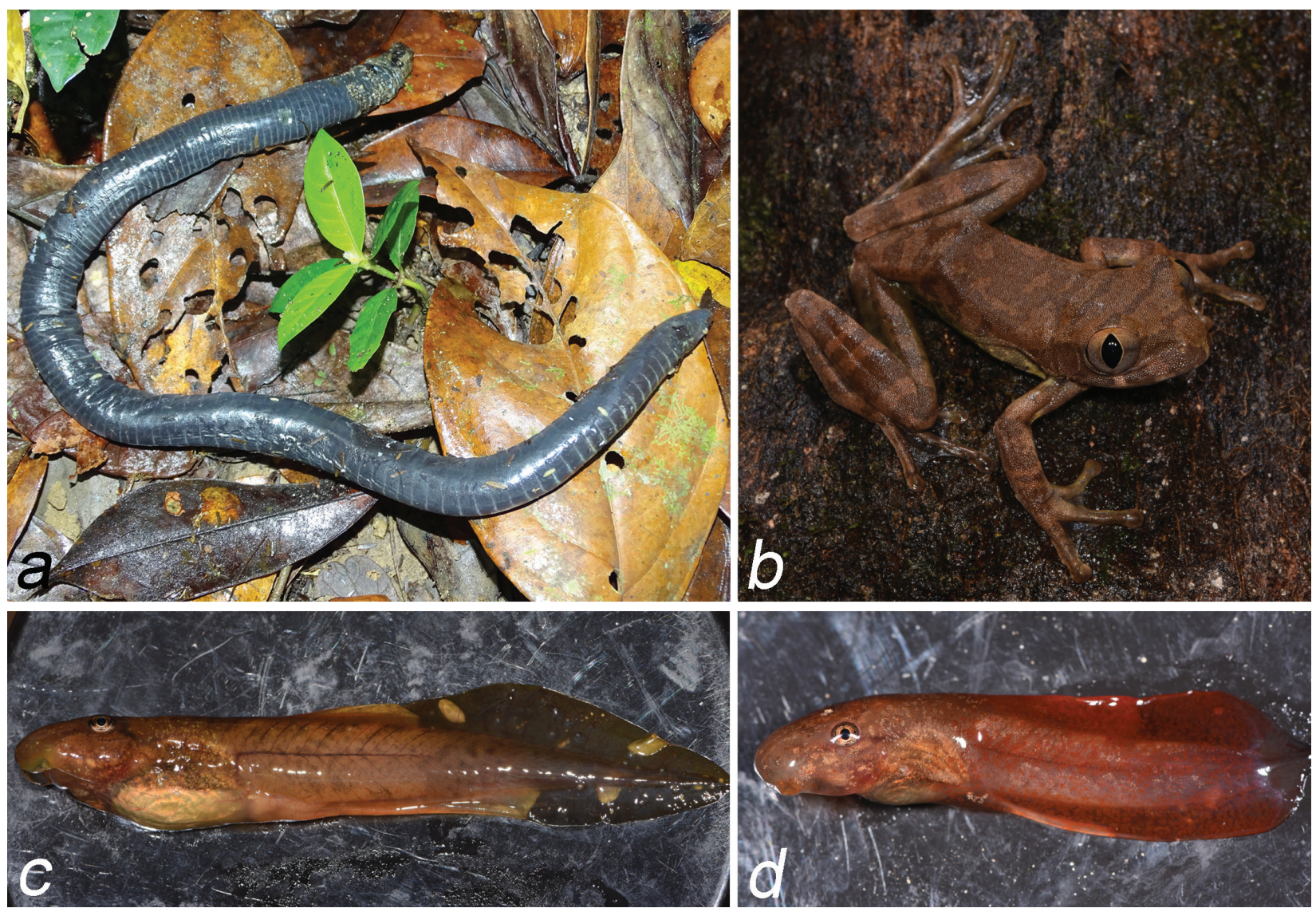

Figure 2. a Geotrypetes sp. (ZMB 88492) found dead in the leaf litter in KBPPA b Leptopelis macrotis male (ZMB 88439) from KBPPA c, d Conraua alleni tadpoles (ZMB 88526) from the same puddle in a small stream in FPPA, take note of the differing color, shape and place of insertion of tail fins.

Cardioglossa occidentalis Blackburn, Kosuch, Schmitz, Burger, Wagner, Gonwouo, Hillers \& Rödel, 2008; KBPPA (ZMB 88462); FPPA (ZMB 88493, 88494)

This species lives in the leaf litter along small rivers in primary and slightly degraded forest from Sierra Leone to Ghana (Rödel et al. 2001; Blackburn et al. 2008).

\section{Astylosternus occidentalis Parker, 1931; KBPPA (ZMB 88457); FPPA (ZMB 88519, 88550)}

This species breeds in clear, in part fast flowing streams within the rainforest. However, adults may be also found at night in leaf litter far away from water. This species occurs in primary and slightly degraded forest of the western part of the Upper Guinea hotspot (Rödel et al. 2012). It was particularly abundant in FPPA.

\section{Leptopelis spiritusnoctis Rödel, 2007; KBPPA (ZMB 88437); FPPA (no voucher)}

A very common small (males) to mid-sized (females) arboreal frog of degraded and primary forests. The quiet chucks and buzzes of adult males can be usually heard at night, a few meters up in dense vegetation near swampy areas (Schiøtz 1967; Rödel 2007; Rödel et al. 2014).

\section{Leptopelis macrotis Schiøtz, 1967; KBPPA (ZMB} 88439, 88440); FPPA (no voucher)

This is a large arboreal frog with distinct black, parallel bands across the back (Fig. 2b). It lives high up in trees in primary forests of the Upper Guinea hotspot. Its meowing call can be heard along rivers (Schiøtz 1967; Rödel et al. 2014).

\section{Leptopelis occidentalis Schiøtz, 1967; KBPPA (no voucher); FPPA (ZMB 88532)}

This is a mid-sized treefrog of primary forest in the western part of West Africa, usually calling from a few meters up in trees, near swampy parts of the forest or forest ponds (Schiøtz 1967; Rödel and Branch 2002).

\section{Leptopelis viridis (Günther, 1869); FPPA (ZMB 88546)}

This is a savanna treefrog which enters the forest zone in areas where forest has been cleared (Schiøtz 1967; Rödel 2000). We heard the species frequently calling and found it around the village and in plantations around FPPA. 


\section{Bufonidae}

Sclerophrys maculata (Hallowell, 1894); KBPPA and FPPA (ZMB 88499)

This is a very common species in the savanna zone and heavily degraded areas in the forest zone, sometimes entering forest along logging roads (Rödel 2000; M.-O. Rödel pers. obs.). It ranges from West Africa into the western part of Central Africa (Poynton et al. 2016).

\section{Sclerophrys togoensis (Ahl, 1924); KBPPA (ZMB 88456); FPPA (RG98, tissue only)}

This toad species lives in primary forests from Togo to Sierra Leone. It breeds in small forest streams, but adults may be found in the leaf litter in all parts of the forest (Rödel and Branch 2002; Rödel and Bangoura 2004; Rödel et al. 2004). Our specimens morphologically fit the syntypes of S. togoensis, as well as the description of S. cristiglans (Inger \& Menzies, 1961), which was described from the Tingi Hills in Sierra Leone. The toads are morphologically very variable but genetically almost indistinguishable across their entire range from Togo to Sierra Leone and Guinea (A. Hillers, M.-O. Rödel et al. unpub. data). Therefore, we regard $S$. cristiglans as a junior synonym of $S$. togoensis.

\section{Conrauidae}

Conraua alleni (Barbour \& Loveridge, 1927); KBPPA (ZMB 88459, 88490); FPPA (ZMB 88496; tadpoles: ZMB 88526, 88527)

This aquatic frog occurs in slow and fast flowing rainforest streams in the western part of the Upper Guinea forests (Lamotte and Perret 1968; Rödel and Branch 2002; Rödel 2003; Rödel and Bangoura 2004). However, a complex of cryptic species seems to be hidden under that name (Hillers et al. 2008; M.-O. Rödel et al. unpubl. data). As the species was described from Liberia, the records in both study areas should be the real $C$. alleni (Barbour and Loveridge 1927, 1930). In a small, sandy to muddy stream in pristine forest of the FPPA, we collected unusually yellowish brown to reddish tadpoles, all belonging to this species, which had differing shapes and tail fins color (Fig. 2c, d). Frogs were found in stagnant parts of streams.

\section{Dicroglossidae}

\section{Hoplobatrachus occipitalis (Günther, 1858); FPPA (no} voucher)

This is a large, fully aquatic species, which is widespread in savannas and degraded habitats throughout tropical Africa (Rödel 2000). It is often consumed as food (Mohneke et al. 2010), which was also confirmed by our guide for FPPA. We only heard it calling a few times in rice fields near the village next to FPPA.

\section{Hyperoliidae}

Afrixalus dorsalis (Peters, 1875); FPPA (ZMB 88525)

This is a leaf-folding frog of the West and Central African forest zone. In gallery forest it usually ranges far into savanna areas (Rödel 2007; Amiet 2012). In the forest zone, it occurs in heavily degraded former forest, often in rice fields, and in swampy areas in secondary growth (Schiøtz $1967,1999)$. We detected it only outside real forest near the village next to FPPA or in areas which have been heavily degraded by former artisanal gold mining.

\section{Afrixalus fulvovittatus (Cope, 1861); FPPA (ZMB} 88539)

This is a leaf-folding frog of the West African forest zone, where it lives in heavily degraded former forest (Schiøtz 1967, 1999; Pickersgill 2007). We detected it in plantations around FPPA and around rice fields near the village (Fig. 3a).

\section{Afrixalus nigeriensis Schiøtz, 1963; KBPPA (ZMB 88489); FPPA (ZMB 88524)}

This is a typical leaf-folding frog of primary closed canopy forest. The frogs are usually calling from high up in trees near forest ponds (Schiøtz 1967, 1999; Rödel and Branch 2002). Our records are only the third and fourth records of this species in Liberia. The previous records are from 2005 (Hillers and Rödel 2007) and 2010 (Hillers 2013).

\section{Hyperolius chlorosteus (Boulenger, 1915); KBPPA (ZMB 88447); FPPA (ZMB 88511)}

The calls of this treefrog are the most common nocturnal sounds along rivers in primary forests of the western part of the Upper Guinea forest zone (Schiøtz 1967, 1999; Rödel and Branch 2002; Rödel 2003; Rödel et al. 2004a). We detected this species in both sites along all streams, from extremely small and slow flowing creeks to the edges of large or torrent rivers.

Hyperolius concolor (Hallowell, 1844); KBPPA (no voucher); FPPA (ZMB 88541-88543)

This reedfrog lives in degraded parts of rainforest, as well as in humid savannas. It is absent from closed canopy forest (Schiøtz 1967, 1999; Rödel 2000). Adult females are green, and males are brown to yellow, often with a dark interorbital triangle, during the day. At night both sexes are more or less uniform yellow. Juveniles often exhibit a dorsal color pattern resembling other reedfrogs, such as H. picturatus, H. sylavticus, or H. zonatus (compare Fig. 4c with Figs 3c, 4a). 

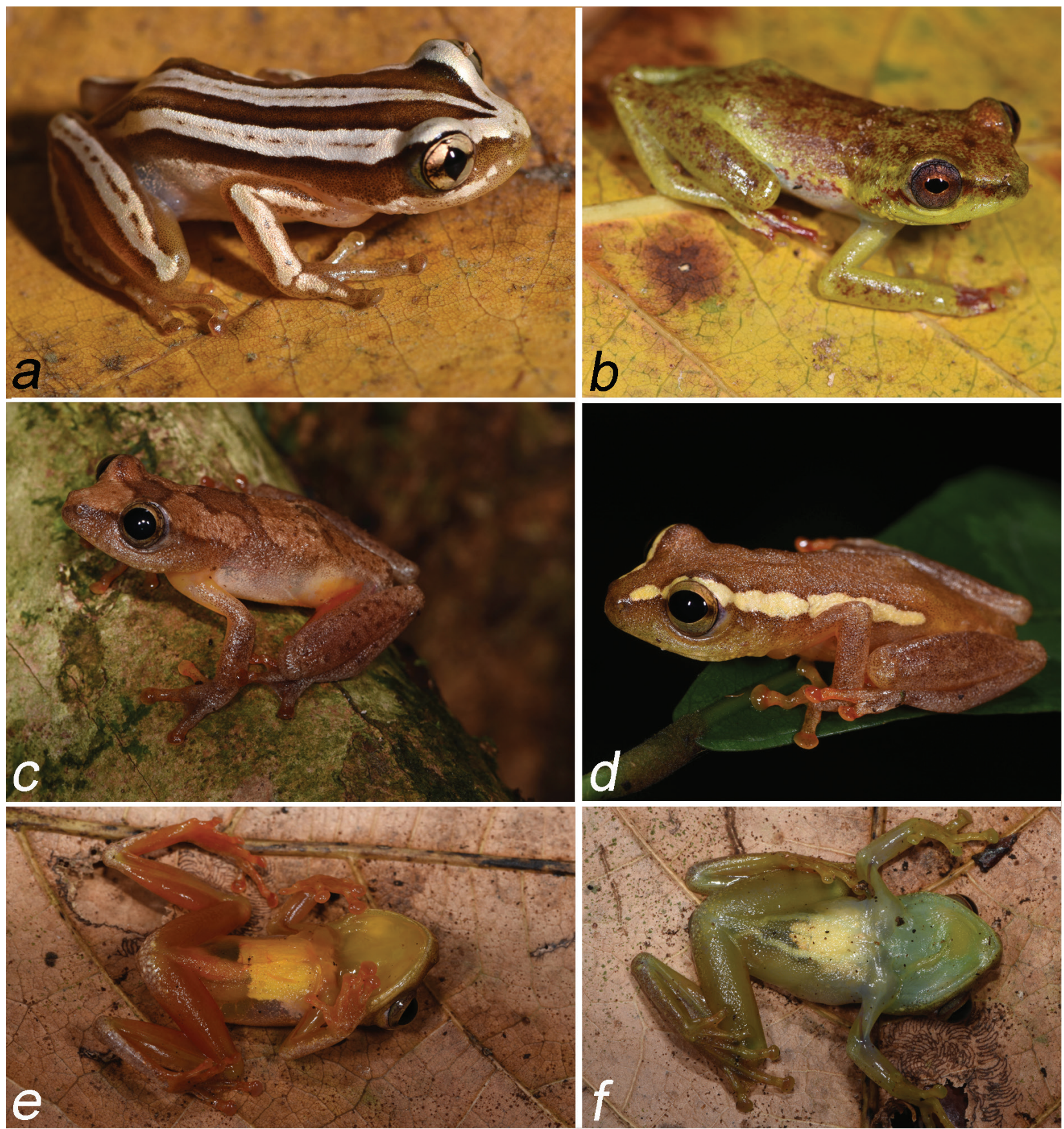

Figure 3. a Juvenile Afrixalus fulvovitattus (ZMB 88539) b Male Hyperolius soror (ZMB 88540), both from farmbush habitats in FPPA, note fine dark lines in the clear bands of A. fulvovittatus, the closely related $A$. vittiger is lacking these lines; c-f) dorsal and ventral views of Hyperolius picturatus $\mathbf{c}$ Female (ZMB 88487) from KBPPA with hourglass pattern, a pattern also often found in combination with dorsolateral line in males d, e Female (ZMB 88464) from KBPPA with common brown back and broad yellow dorsolateral bands and yellow venter $\mathbf{f}$ Translucent greenish venter of male (ZMB 88465) from KBPPA.

\section{Hyperolius fusciventris Peters, 1876; KBPPA (ZMB 88491) and FPPA (no voucher)}

This small reedfrog occurs in the rainforest zones of western Africa (Schiøtz 1967, 1999; Rödel 1998; Amiet 2012). Several subspecies have been described that might deserve full species status (Schiøtz 1967; M.-O. Rödel unpubl. data). They are absent from closed canopy forest and most abundant in secondary growth and forest edges where they breed in swamps and ponds.

\section{Hyperolius guttulatus Günther, 1858; KBPPA (no voucher); FPPA (ZMB 88531)}

This is a reedfrog of the western African rainforest and southern savanna zone, where it usually lives in and 
around open ponds with densely vegetated banks. It avoids closed forest (Schiøtz 1967, 1999; Rödel 2000; Amiet 2012; Kouamé et al. 2015). We detected this species in both areas but only in rice fields around the villages and in small ponds in parts of the forests which were heavily degraded due to prior artisanal mining activities.

\section{Hyperolius picturatus Peters, 1875; KBPPA (ZMB 88463-88488); FPPA (ZMB 88523)}

This reedfrog occurs in secondary growth and degraded forest habitats from Sierra Leone to central Ghana. It breeds in stagnant and slow flowing waters (Schiøtz 1967, 1999; Rödel and Branch 2002; Rödel and Bangoura 2004). It seems to comprise at least two different species (Schiøtz 1967). In KBPPA and FPPA, our female records were morphologically similar to animals from western Côte d'Ivoire in having a yellow belly, but males had green instead of yellow gular glands and almost transparent bellies (Fig. 3f). Most specimens had brown backs with irregular to distinct sharp-edged, yellow dorsolateral bands (Fig. 3d). Some showed brown backs with an hourglass pattern (Fig. 3c); thus, they are very similar to H. sylvaticus Schiøtz, 1967 and H. zonatus (Schiøtz 1967; Rödel and Branch 2002).

\section{Hyperolius soror (Chabanaud, 1921); FPPA (ZMB 88540)}

This reedfrog is only known from the western part of the Upper Guinea forest zone. It seems to be more closely associated with primary rainforest than the related H. fusciventris (Schiøtz 1967, 1999; Rödel 1998). However, we detected one male frog at the forest edge of FPPA (Fig. 3b).
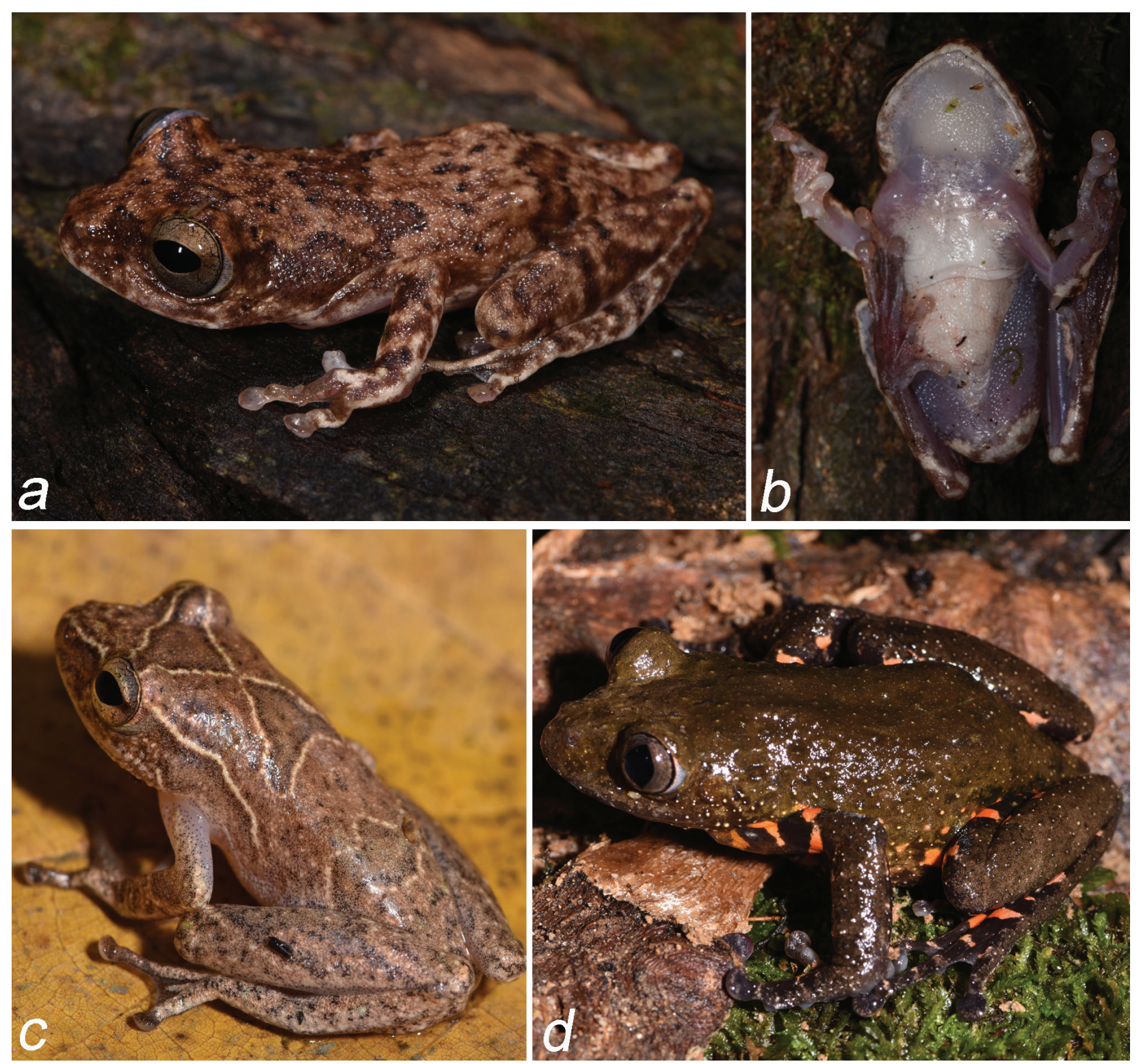

Figure 4. a, b Dorsal and ventral view of male Hyperolius zonatus (ZMB 88446) from KBPPA, showing the white gular region with the roundish gland, lacking dilatable skin of a larger vocal sac $\mathbf{c} H$. concolor (ZMB 88542) with juvenile pattern from FPPA d male Phlyctimantis boulengeri (ZMB 88514) from FPPA. 
Hyperolius zonatus Laurent, 1958; KBPPA (ZMB 88446); FPPA (ZMB 88522)

This reedfrog occurs only in primary forest (Fig. 4a) from eastern Sierra Leone, southeastern Guinea, Liberia, to western and central Côte d'Ivoire (Schiøtz 1967, 1999; Rödel and Branch 2002; Rödel et al. 2004). It is best distinguished from the morphologically very similar H. sylvaticus by the small, white gular gland (in contrast to a larger yellow one) and the almost absence of an extendable vocal sac in males (Fig. 4b). This species breeds in stagnant forest waters.

\section{Phlyctimantis boulengeri Perret, 1986; FPPA (ZMB 88514)}

This is a large treefrog of the western Africa forest zone and occurs at forest edges and along dense vegetation of larger ponds (Schiøtz 1967, 1999; Rödel and Ernst 2001; Rödel et al. 2004a). We found the species in FPPA only in forest areas, which were heavily degraded due to former artisanal gold mining (Fig. 4d). We also heard them calling along open swampy areas near the village.

\section{Odontobatrachidae}

Odontobatrachus natator (Boulenger, 1905); FPPA (ZMB 88530, 88534)

The sable-toothed frog was, in part, very common along rocky creeks and rivers in primary and slightly degraded forests of FPPA. Morphologically similar species have been recently described within this genus (Barej et al. 2015), but based on the ranges published of these species, we assign our records to $O$. natator.

\section{Phrynobatrachidae}

\section{Phrynobatrachus alleni Parker, 1936; KBPPA (ZMB 88444)}

This is a typical frog of primary and slightly degraded forests of the Upper Guinea forest zone (Guibé and Lamotte 1963; Rödel and Branch 2002; Rödel 2003; Rödel and Ernst 2004). They have a very distinctive head shape and scapular ridges forming an X (the two 'arms' of the X are not connected in the center) which does not extend beyond half of the back. Males have distinctive bright-yellow throats and bellies, they reproduce in slow-flowing parts of small forest streams and puddles of swamps. Many different color morphs are known (M.-O. Rödel unpubl. data), and breeding males may turn completely yellow (Rödel 2003).

Phrynobatrachus aff. alleni; KBPPA (ZMB 8846088461, 88474-88475, 88479-88484); FPPA (ZMB 88498)

These frogs are morphologically very similar to the previous species; however, adult males present distinctly different ventral coloration. These color differences are reflected by genetic differences (M.-O. Rödel and J. Glos unpubl. data). However, as $P$. alleni was described from Liberia and both taxa seem to be represented in the type series (M.-O. Rödel unpubl. data), it is so far unclear which of the two taxa represent the real P. alleni. The taxonomy of these frogs and the description of a new species will be the subject of a separate publication.

\section{Phrynobatrachus calcaratus (Peters, 1863); KBPPA (no voucher)}

These frogs comprise a complex of cryptic species (Rödel and Agyei 2003; Zimkus et al. 2010), which have been reported from forests and forested savanna from West to western Central Africa (Rödel 2000; Frost 2018). We only detected one individual in the leaf litter of a dry river bed in a closed canopy forest in KBPPA. Unfortunately this frog escaped.

\section{Phrynobatrachus fraterculus (Chabanaud, 1921); FPPA (ZMB 88506)}

This is a species of degraded forest and forest edges in the western part of the Upper Guinea forest region (Guibé and Lamotte 1963; Rödel and Bangoura 2004; Blackburn 2005; Rödel et al. 2009c). We found only one juvenile in FPPA.

\section{Phrynobatrachus guineensis Guibé \& Lamotte, 1962; KBPPA (no voucher)}

This is a species specialized to breed in water-filled tree holes in rainforests (Rödel et al. 2004). It is currently known from western Côte d'Ivoire, south-western Guinea and eastern Liberia (Guibé and Lamotte 1963; Rödel et al. 2004b; Hillers and Rödel 2007). We found this species in low abundance and very patchily distributed in drier parts of the closed canopy forest in KBPPA.

\section{Phrynobatrachus gutturosus (Chabanaud, 1921); KBPPA and FPPA (no vouchers)}

This species was originally described from Sanikolé, Liberia (Chabanaud 1921). Currently, records are known from primary rainforest (Rödel and Ernst 2004), as well as from savanna from various parts of West African (Rödel 2000; Nago et al. 2006). It apparently is a complex of cryptic species (Zimkus et al. 2010; Ofori-Boateng et al. 2018), but our records are likely the real P. gutturosus, as the type locality is in Liberia (Chabanaud 1921). In both sites, usually near stagnant waters in primary forest, we heard this species' typical long buzzing call with single clicks at the end.

\section{Phrynobatrachus cf. gutturosus/tokba; KBPPA (ZMB 88435, 88436)}

In drier parts of primary forest, near camp 1 in KBPPA, we found numerous small Phrynobatrachus which mor- 


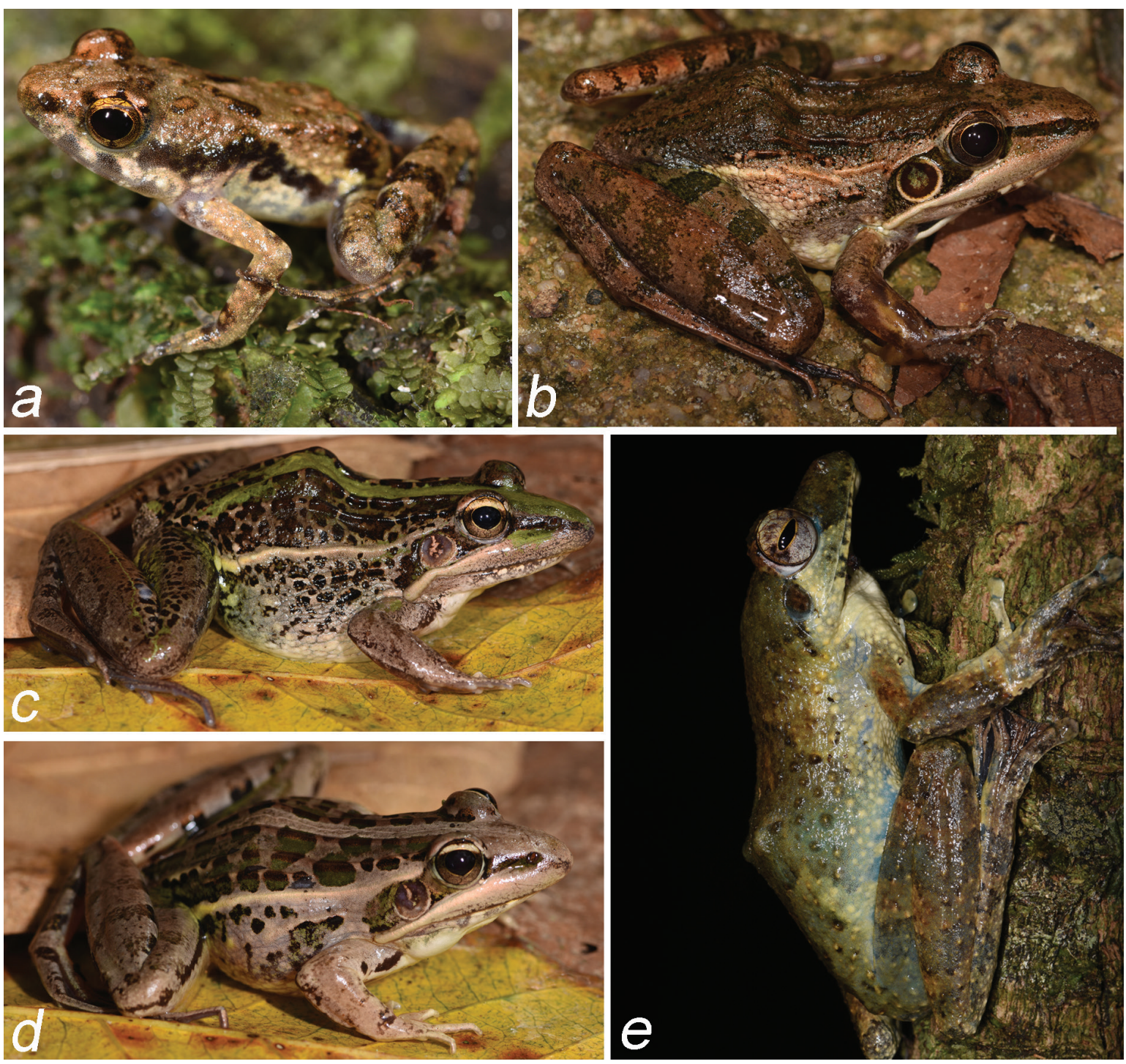

Figure 5. a Undescribed Phrynobatrachus sp. from KBPPA exhibiting characters of P. gutturosus and P. tokba b Ptychadena sp. male (ZMB 88505) from river bank in FPPA c, d Ptychadena mascareniensis-complex females with green (c: ZMB 88535) and brown (d: ZMB 88537) vertebral bands from the same rice paddy in FPPA e Chiromantis rufescens female (not collected) from KBPPA.

phologically were most similar to $P$. gutturosus and $P$. tok$b a$ (Fig. 5a). Barcoding revealed that they were identical to Phrynobatrachus aff. gutturosus sensu Zimkus et al. (2010). A taxonomic clarification of these frogs requires the revision of the P. gutturosus-complex (Ofori-Boateng et al. 2018).

\section{Phrynobatrachus latifrons Ahl, 1924; FPPA (ZMB 88544, 88545)}

This species occurs from heavily degraded rainforest habitats throughout all of West and western Central African savanna habitats into the southern Sahara (Rödel 2000; Trape 2015). We found it near FPPA around the village in burned swampy areas which were being prepared to be turned into rice paddies.

\section{Phrynobatrachus liberiensis Barbour \& Loveridge, 1927; KBPPA (ZMB 88449, 88478); FPPA (ZMB 88495)}

This is a species typical for swampy primary forests, where they occur near slow-flowing, often very shallow streams (Rödel and Branch 2002; Kouamé et al. 2018). This species was recorded from Sierra Leone to western Nigeria (Onadeko and Rödel 2009; Rödel et al. 2009b). Several genetic lineages are known across its range (Kpan et al. 2018), but the type locality is in Liberia (Barbour and Loveridge 1927).

\section{Phrynobatrachus phyllophilus Rödel \& Ernst, 2002; KBPPA (no voucher); FPPA (ZMB 88502)}

This is a characteristic species of swampy primary forest from eastern Côte d'Ivoire to Sierra Leone (Rödel and Ernst 2002b; Kouamé et al. 2008, 2018). 


\section{Phrynobatrachus plicatus (Günther, 1858); KBPPA (ZMB 88445)}

This is a large species of Phrynobatrachus and is distributed from eastern Liberia to western Nigeria (Guibé and Lamotte 1963; Lamotte and Xavier 1966; Rödel et al. 2009 b). It inhabits primary and slightly degraded rainforest and often breeds in puddles of forest roads (Rödel and Branch 2002; Kouamé et al. 2018).

Phrynobatrachus 'sp. Gola'; FPPA (ZMB 88497, 88520, 88521)

This species is morphologically almost identical to, but genetically different from, P. plicatus (A. Hillers and M.-O. Rödel unpub. data). It seems to be restricted to rainforests of the Sierra Leone-Liberia border region. A formal description of this species will be made in a separate publication.

\section{Phrynobatrachus tokba (Chabanaud, 1921); KBPPA (no voucher); FPPA (ZMB 88503)}

This small leaf-litter frog is known from western Guinea to Ghana (Guibé and Lamotte 1963; Rödel et al. 2004a, 2005b; Hillers et al. 2007). It deposits its clutches outside of water in moist leaves and has non-feeding, non-hatching tadpoles (Rödel and Ernst 2002a). This species occurs in primary forest but is most abundant in degraded forests and may even enter moist savanna adjacent to forest (Rödel 2003; Rödel and Bangoura 2004; Ernst and Rödel 2005). We heard it very frequently calling along forest edges and open forests at both sites.

\section{Phrynobatrachus villiersi Guibé, 1959; KBPPA (ZMB 88448, 88473)}

This is a very small leaf-litter frog, which is known to occur patchily from Ghana to Liberia in swampy parts of primary rainforest (Guibé 1959; Rödel and Branch 2002; Hillers and Rödel 2007; Ernst and Rödel 2008; Hillers et al. 2009). The record in KBPPA is only the second record of this species in Liberia (Hillers and Rödel 2007).

\section{Ptychadenidae} Ptychadena aff. aequiplicata; KBPPA (ZMB 88441,
88442, 88455); FPPA (ZMB 88510)

This is a typical rocket frog of leaf litter of lowland rainforests with terrestrial egg deposition (Rödel et al. 2002a). In contrast to previous assumptions (Guibé and Lamotte 1957, 1958b; Perret 1966), this species is not continuously distributed from West to Central Africa, but comprises various genetic lineages (M.F. Barej and M.-O. Rödel et al. unpubl. data). In KBPPA, we found frogs from two clades, ZMB $88441 / 88442$ and ZMB 88455, respectively. ZMB 88510 from FPPA belonged to the same clade as ZMB 88455. The taxonomy of these frogs is currently being revised.
Ptychadena cf. bibroni (Hallowell, 1845); KBPPA and FPPA (no voucher)

This is a typical rocket frog living in savanna and degraded forest habitats, where it breeds in stagnant puddles and pools (Rödel 2000). We heard this species at the edges of forest and along the banks of a large river. As we could not collect a voucher, our identification is based on call characters only.

Ptychadena longirostris (Peters, 1870); KBPPA (ZMB 88432, 88443); FPPA (ZMB 88513, 88515; tadpoles: 88508)

This forest frog prefers open areas and puddles on forest roads where they may congregate to large choruses (Guibé and Lamotte 1954; Rödel 2000). We often found this species in former artisanal gold mining areas (Fig. 1c).

\section{Ptychadena mascareniensis-complex; FPPA (ZMB 88535-88538)}

This is a complex of rocket-frog species ranging across the whole of sub-Saharan Africa, Madagascar, the Seychelles, and the Mascarene Islands (Vences et al. 2004; Zimkus et al. 2017). The various lineages all live in open savanna-like habitats and often in rice paddies (Rödel 2000; Glaw and Vences 2007). We found it exclusively in the rice paddies surrounding the village near FPPA. Frogs of both sexes had either brown or green vertebral bands, even when coming from the same habitat (Fig. 5c, d).

\section{Ptychadena sp.; FPPA (ZMB 88505, 88548, 88517, 88518)}

We found these frogs (Fig. 5b) in very heavily degraded forest in areas of former artisanal gold mining, where they occurred along the banks of a medium-sized river. We heard their very distinctive croaking advertisement call in swampy areas around the village near FPPA. We have been unable to assign them to any of the described West African species of Ptychadena (Guibé and Lamotte 1957, 1958a; Lamotte and Ohler 1997, 2000; Perret 1997; Rödel 2000).

\section{Pyxicephalidae}

\section{Aubria subsigillata (Duméril, 1856); KBPPA (ZMB 88433, 88434)}

This is an aquatic frog, known to feed, amongst other prey, on small fish (Knoepffler 1976, Hughes 1979). The taxonomy is not entirely clear (Ohler and Kazadi 1990). West African populations have been described as $\mathrm{A}$. occidentalis (Perret 1994), but were later synonymized with A. subsigillata by Ohler (1996). According to our experience specimens with red or beige colors occur across all habitats (Assemian et al. 2006, Rödel et al. 2005a, 

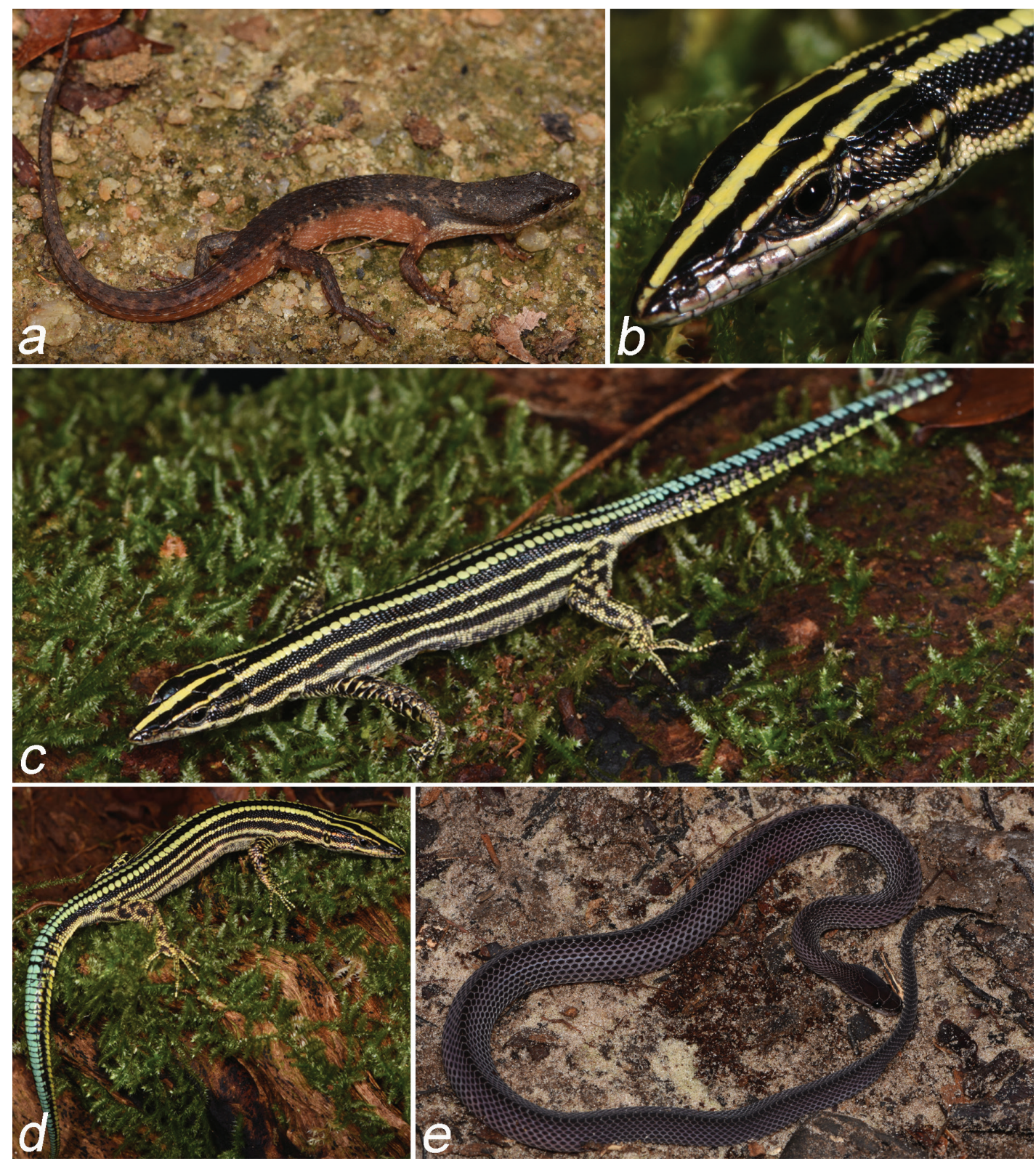

Figure 6. a Cophoscincopus simulans male (ZMB 88507) from FPPA b, c Holaspis guentheri male (ZMB 88471) d Holaspis guentheri female (ZMB 88472) from KBPPA e Juvenile Goniontophis klingi (ZMB 88467) from KBPPA.

2007). We found various individuals of this species in an isolated part of a river in primary forest of KBPPA. The shallow to deep pond had no vegetation, neither on the banks nor submerged. The frogs were sitting along the sandy banks, instantly jumping into the water when disturbed (Fig. 1a).

\section{Ranidae}

Amnirana 'albolabris-West'; KBPPA (ZMB 88438, 88458); FPPA (ZMB 88512, 88549; tadpoles: 88528)

This is a median-sized to large leaf-litter frog which was believed to range from forested West Africa into western East Africa. Very recently Jongsma et al. (2018) showed that the Upper Guinea populations are a separate, undescribed species, which is the oldest lineage of the entire clade.

\section{Amnirana occidentalis (Perret, 1960); FPPA (ZMB 88501)}

A large leaf-litter frog patchily distributed along rainforest streams of the Upper Guinea forests (Perret 1960, 1983, Rödel and Branch 2002, Rödel and Bangoura 2004, Rödel et al. 2004a, Hillers and Rödel 2007).

\section{Rhacophoridae}

\section{Chiromantis rufescens (Günther, 1869); KBPPA (no voucher); FPPA (ZMB 88516)}

This is a complex of treefrogs which is widespread in West and Central African rainforests (Schiøtz 1999; Amiet 2012; A. Leaché et al. unpubl. data). In contrast to all other West African frogs, they deposit their eggs in foam 
nests above water to minimize predation. In West Africa, monkeys are known to feed regularly on these nests and may be the main predator of this species (Rödel et al. 2002). We found this species at both sites along stagnant rivers, near forest ponds, and in puddles, in primary as well as in highly degraded parts of the forest, including areas which have been heavily transformed by previous artisanal gold mining (Fig. 5e). These records are only the third and fourth records of this species in Liberia (Hillers and Rödel 2007; Hillers 2013).

\section{Reptilia \\ Testudines \\ Trionychidae}

Trionyx triunguis (Forskål, 1775); KBPPA (no voucher)

According to our guide, these large soft-shelled turtles use a particular sandbank of one large river as their breeding site in KBPPA. We confirmed the presence of this species there by a carapace kept in the nearby village. This species is widely distributed in rivers and forests along Africa's western coast, but it is rarely encountered. It has been previously reported from Liberia (Gramentz 2005).

\section{Crocodylia \\ Crocodylidae}

Osteolaemus tetraspis Cope, 1861; KBPPA (no voucher)

We encountered an adult specimen (103 cm length) of this threatened dwarf crocodile at night, near a swampy part of primary rainforest in KBPPA. This species was believed to be widely distributed in forests of West and western Central Africa (Villiers 1958; Trape et al. 2012), where it lives in rainforest, but it may be encountered further north, following gallery forests deep into the savanna zone (Rödel and Garbow 1995). Recent analyses suggest that West Africa is inhabited by two species of dwarf crocodiles, which are both distinct from the Central African O. osborni Schmidt, 1919 (Brochu 2007; Shirley et al. 2014).

\section{Sauria}

Agamidae

Agama agama (Linnaeus, 1758); KBPPA and FPPA (no voucher)

These common rock- and tree-dwelling lizards (Trape et al. 2012) were often observed in all villages and all disturbed non-forested areas in both sites. We observed no other rainbow agama during our survey. We identified the species as A. agama, following Trape et al. (2012). However, more recent work by Leaché et al. (2014, 2017) on the systematics of these lizards suggest that Agama picticauda Peters, 1877 is likely the valid name for our populations.

\section{Gekkonidae}

\section{Hemidactylus fasciatus Gray, 1842; KBPPA (no voucher)}

This widespread West African forest gecko (Trape et al. 2012; Wagner et al. 2014) was only observed once at night on the base of a tree trunk. This was in an area impacted by former artisanal gold mining.

Hemidactylus muriceus Peters, 1870; KBPPA (ZMB 88450); FPPA (no voucher)

This is a widespread species in western African forests (Trape et al. 2012), which we occasionally encountered in both sites at night on smaller trees and shrubs or even in the leaf litter (Henle and Böhme 2003).

\section{Lacertidae}

Holaspis guentheri Gray, 1863; KBPPA (ZMB 88471, 88472)

This is an arboreal lizard of West and Central African rainforests and occurs east to Uganda (Spawls et al. 2004; Trape et al. 2012). We collected two specimens during the day in a clearing in the KNPPA while they were chasing each other to the ground. This represents the first record of this elusive lizard for Liberia (Fig. 6b-d).

\section{Scincidae}

\section{Cophoscincopus simulans (Vaillant, 1884); FPPA (ZMB 88500, 88507, 88509)}

Water skinks were occasionally encountered in the leaf litter along small streams in primary forest of FPPA (Fig. 6a). They are widespread in West African rainforests (Böhme et al. 2000; Trape et al. 2012).

\section{Trachylepis affinis (Gray, 1838); KBPPA and FPPA (no voucher)}

This skink is frequently seen in clearings or degraded parts of the forest. This species-complex is widely distributed in forests (rainforest and the humid savanna zone) of West and Central Africa (Freedman et al. 2010; Trape et al. 2012; Allen et al. 2017; Uetz 2018).

\section{Trachylepis maculilabris (Gray, 1845); KBPPA and FPPA (no voucher)}

This skink is broadly distributed throughout Africa (Trape et al. 2012; Uetz 2018). We found it at both sites, usually in forest clearings. For a key to West and western Central African Trachylepis, see Allen et al. (2017). 

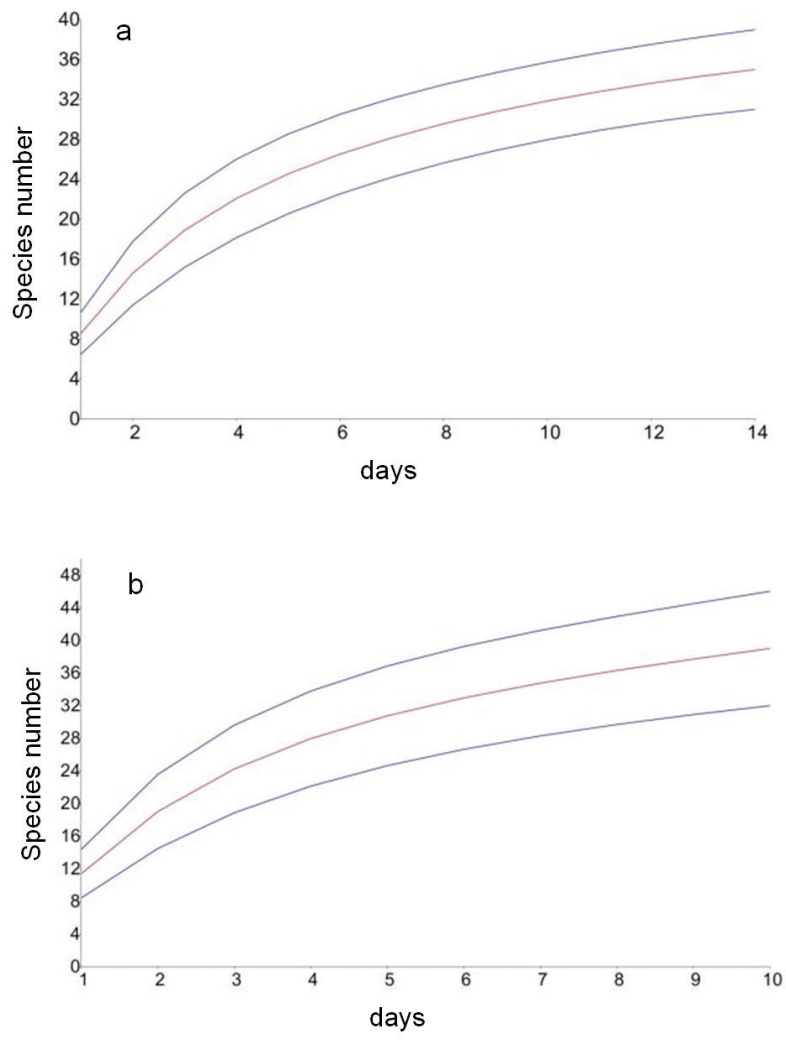

Figure 7. Permutated species accumulation curves (=sample-based rarefaction curve; red line: mean, blue lines: 95\% confidence intervalls) of amphibian species richness in a the Krahn-Bassa Proposed Protected Area in eastern Liberia and $\mathbf{b}$ the Foya Proposed Protected Area in western Liberia during the March/April 2018 survey. Y-axis: estimated amphibian species richness, $\mathrm{x}$-axis: sample units (each comprising six to $16 \mathrm{man} /$ hour surveys in different localities within the respective areas).

\section{Varanidae}

Varanus ornatus Gray, 1845; KBPPA and FPPA (no voucher)

We observed adult specimens foraging during the day in the leaf litter of drier parts of the rainforest. The validity of this taxon was recently doubted, and it was consequently synonymized by Dowell et al. (2015) with $V$. niloticus (Linnaeus, 1766), although distinct genetic lineages were found within their samples (Uetz 2018). As we (here and elsewhere in West Africa) can easily assign monitor lizards to either $V$. niloticus or $V$. ornatus, following Böhme and Ziegler (1997) in considering the number of transverse rows of spots across body, the color of the tongue, and different ecological requirements (and in order to make later assignments of records to different taxa possible), we do not follow the arguments from Dowell et al. (2015) and treat our observations as being distinct from $V$. niloticus sensu stricto.

\section{Serpentes \\ Colubridae}

Afronatrix anoscopus (Cope, 1861); KBPPA (ZMB 88469)

We collected at night in KBPPA one specimen of these common aquatic snakes. This species ranges from Senegal to Cameroon (Chippaux 2001). Individuals of this species were foraging in ponds and puddles near a small forest creek originating from a former artisanal gold mining area.

\section{Toxicodryas blandingii (Hallowell, 1844); FPPA (no voucher)}

In FPPA, we observed at night a large adult snake high in the trees over a rocky torrential stream, apparently searching for food. The species has a wide distribution from Guinea in the west to Kenya in the east and mostly is living in forest habitats (Chippaux 2001).

\section{Lamprophiidae \\ Atractaspis sp. n.; FPPA (ZMB 88529)}

We collected a stiletto snake at night in FPPA on the steep banks of a rocky stream in primary rainforest. A detailed comparison of characters among all described species of Atractaspis revealed that our specimens is an undescribed species. This taxon will be formally described elsewhere.

\section{Boaedon lineatus Duméril, Bibron \& Duméril, 1854; FPPA (ZMB 88547)}

We found a juvenile snake in a degraded area near a small stream in a cleared area surrounded by forest. This species is widespread in forest and savanna habitats in West Africa (Chippaux 2001).

\section{Gonionotophis klingi Matschie, 1893; KBPPA (ZMB 88467)}

This West African species lives in leaf litter in rainforests (Rödel and Mahsberg 2000). Chippaux (2001) did not include it in his list of species in Liberia, but Uetz (2018) did include the country within its range. We caught our juvenile specimen at night in leaf litter in a drier part of the forest in KBPPA (Fig. 6e).

\section{Lycophidion nigromaculatum (Peters, 1863); KBPPA (ZMB 88468); FPPA (no voucher)}

In KBPPA, this terrestrial, lizard-eating snake was found at night near a small pond in an area of former artisanal gold mining. In FPPA it was found at night climbing on a tree trunk which was bridging a small forest stream. This 
species lives in West African rainforests and is known from Ghana to eastern Liberia (Chippaux 2001). According to Chippaux's (2001) map, our FPPA record would seem to be the westernmost record for the species. However, the species has been also found in the Gola National Park in Sierra Leone (M.-O. Rödel unpubl. data).

\section{Viperidae}

\section{Atheris chlorechis (Pel, 1852); KBPPA (no voucher)}

This is a species of small arboreal viper, which is widely distributed in the Upper Guinea rainforests (Rödel and Masberg 2000; Chippaux 2001). We observed several specimens of various ages in primary parts of KBPPA.

\section{Additional species}

In KBPPA we also found the skin of a large snake, most likely a forest cobra, Naja guineensis Broadley, Trape, Chirio, Ineich \& Wüster, 2018 (Wüster et al. 2018). An adult forest cobra was observed in the morning on the main road, when driving back to Monrovia. We received reliable descriptions from our guides for the following species: slender-snouted crocodile Mecistops cataphractus (Cuvier, 1825); tortoises, most likely Kinixys homeana Bell, 1827 and Kinixys erosa (Schweigger, 1812); freshwater turtles, Pelusios spp.; and two large forest vipers, Bitis nasicornis (Shaw, 1802) and Bitis rhinoceros (Schlegel, 1855). We also believe, based on published records in other Liberian forests and nearby Taï National Park in Côte d'Ivoire (Rödel and Ernst 2004; Hillers and Rödel 2007), that the following frogs and toads should also occur in KBPPA: Sclerophrys chevalieri (Mocquard, 1908)[treated as subspecies of S. superciliaris (Boulenger, 1888) in Barej et al. 2011], Sclerophrys taiensis (Rödel \& Ernst, 2000), Phrynobatrachus annulatus Perret, 1966, Acanthixalus sonjae Rödel, Kosuch, Veith \& Ernst, 2003, Afrixalus vibekensis Schiøtz, 1967, Kassina lamottei Schiøtz, 1967, Kassina cochranae (Loveridge, 1941), and Ptychadena superciliaris (Günther, 1858).

In FPPA, our guide and various villagers gave reliable descriptions of the following additional species: rainbow toad, Sclerophrys chevalieri; rock python, Python sebae (Gmelin, 1789); crocodiles, Osteolaemus tetraspis and Mecistops cataphractus; tortoises, Kinixys spp.; turtles, Pelusios spp.; forest vipers, Bitis nasicornis and Bitis rhinoceros; and cobra, Naja guineensis. A previous preliminary survey in FPPA (SNCL 2017) revealed the presence of the frogs: Phrynobatrachus annulatus, P. villiersi, Ptychadena oxyrhynchus (Smith, 1849), and Afrixalus vibekensis, and the reptiles Lepidothyris fernandi (Burton, 1836) and Dipsadoboa brevirostris Sternfeld, 1908 (identified from photos by A. Hillers). Based on their presence at other Liberian (Hillers and Rödel 2007; A. Hillers unpub. data) and nearby Sierra Leonean sites, the presence in FPPA of Sclerophrys taiensis and Ptychadena superciliaris is likely.

\section{Amphibian diversity}

Because our data for amphibians are much more complete than those for reptiles, we only analyse the former. We found at both sites combined a minimum of 49 amphibian species (1 caecilian, 48 anurans) but did not count cryptic species within, e.g., the $P$. aequiplicata-complex.

In KBPPA, we recorded 36 amphibian species (1 caecilian, 35 anurans), which were mostly forest specialists and included only a very few open-habitat species (Table 2). Twenty-four species are only known from the Upper Guinea forests and half of them even only from the western part of this biodiversity hotspot. Less than a third of the species occur across West and western Central Africa ( 8 species) or have even larger ranges ( 2 species; Table 2). Of the species recorded, the majority is dependent on rainforest and has restricted ranges within West Africa. Only two species are listed by the IUCN as threatened (both Vulnerable; Conraua alleni and Phrynobatrachus villiersi). Most species are either not assessed or are lower risk, assessed as Near Threatened or Least Concern. Species richness estimators estimated species richness in KBPPA as $38.7 \pm 3.5$ (mean $\pm \mathrm{SD}$; Chao 2) and $43.4 \pm 3.2$ (Jackknife 1). This and the species accumulation curve (Fig. 7a) indicate that the species list is not complete but shows a good representation of the amphibian species community active in KBPPA at the time of the survey.

In FPPA, we recorded 39 amphibian species (all anurans), with most being forest specialists and less than a quarter typically from open habitats (Table 2). Twenty-five species are only known from the Upper Guinea forests, and half of these are known only from the western part of this biodiversity hotspot. Less than a quarter of the species occur across West and western Central Africa ( 8 species) or have even larger ranges (4 species; Table 2). Most species recorded in FPPA are dependent on rainforest and have restricted ranges within West Africa. Only two species are listed by the IUCN as being threatened (Vulnerable, Conraua alleni and Endangered, Amnirana occidentalis). Most species have not yet been assessed or they are lower risk, assessed as Near Threatened or Least Concern. Species richness estimators estimated species richness in FPPA as $53.0 \pm 10.6$ (mean $\pm \mathrm{SD}$; Chao 2) and $50.7 \pm 4.7$ (Jackknife 1). This and the species accumulation curve (Fig. $7 \mathrm{~b}$ ) indicate that the species list is not complete and that considerably more ( $>$ 10) species should be expected in the amphibian community in FPPA.

\section{Discussion}

Whereas we obtained a very good overview of the amphibian fauna, the reptile data are too incomplete to allow for meaningful discussions. We recorded a few interesting reptile species, but for snakes more than 50 species might be expected in both sites (e.g. Roux-Esteve 1969; 
Böhme 2000; Rödel and Mahsberg 2000). Of special importance was our first country record of Holaspis guentheri and the discovery of a new species of Atractaspis. In the following we will focus on the amphibian data of our survey.

We recorded between 36 and 39 amphibian species at both sites, and we estimated the presence of another 15-20 species that we could not find. Compared to data available from other forest sites within the western part of the Upper Guinea forest region (Rödel and Branch 2002; Rödel and Bangoura 2004; Rödel and Ernst 2004; Rödel et al. 2004a; Hillers and Rödel 2007), this estimate seems realistic. Given that we only surveyed for a short time in small areas, the estimates are likely to be at the lower range of what might be expected in these forests. Our data also support former findings, that the western part of the Upper Guinea forest hotspot has a higher amphibian species richness than the equally unique forests further east (Rödel and Agyei 2003; Rödel et al. 2005a, 2007; Leaché et al. 2006; Hillers et al. 2009; Kpan et al. 2014).

We found the amphibian and reptile fauna in KBPPA to be very similar, but not identical to that of Taï National Park in Côte d'Ivoire (Rödel and Ernst 2004; Ernst and Rödel 2006). The two potentially new Phrynobatrachus species underline the uniqueness of KBPPA. In FPPA, the presence of an undescribed species of Phrynobatrachus, Odontobatrachus natator, and a potentially new species of Ptychadena, indicate a fauna similar to KBPPA, but still clearly distinct and including unknown species.

We conclude that both KBPPA and FPPA have very high conservation values, based on the amphibian species richness, which is due to the high proportion of forest specialists, species with restricted ranges, undescribed taxa, and our estimate that more species should be detectable. However, these areas were seriously affected by artisanal logging and mining, agricultural encroachment, and hunting. These principal threats lend urgency to the immediate protection of the remaining forests. As our data and the published faunal list of Hillers and Rödel (2007) show, the formerly vast rainforests of Liberia may harbor local species assemblages, including species new to science. This conclusion also applies to the whole country as well (compare predictions by Penner et al. 2019), and therefore, the remaining areas of forest should be desperately surveyed, not only for amphibians and reptiles, but for as many animal and plant taxa as possible. Whenever possible, such efforts should include the training of Liberian biologists, who are needed to establish the necessary long-term expertise in the country for maintaining its unique biodiversity.

\section{Acknowledgements}

We thank the Wild Chimpanzee Foundation and the Society for the Conservation of Nature of Liberia, their employees in general, and Annika Hillers and Jerry Garteh in particular for the invitation to conduct our survey and for all the logistic support! Without the various drivers, guides, porters, and cooks, the survey would not have been possible. Thank you all for your support! Alan Channing and Philipp Wagner provided valuable comments to a previous draft of the manuscript. Comments by Robert Forsyth improved the language. Finally, we thank the Forestry Development Authority (FDA) of the Republic of Liberia for the permission to survey these forests and the collection and export permits (Ref: MD/037/2018/11).

\section{References}

Allen KE, Tapondjou NWP, Welton LJ, Bauer AM (2017) A new species of Trachylepis (Squamata: Scincidae) from Central Africa and a key to the Trachylepis of West and Central Africa. Zootaxa 4268: 255-269. https://doi.org/10.11646/zootaxa.4268.2.5

Amiet JL (2012) Les rainettes du Cameroun. Édition J.-L. Amiet \& La Nef des Livres, Nyons/Saint Nazaire, 591 pp.

Assemian NE, Kouamé NG, Tohé B, Gourène G, Rödel MO (2006) The anurans of the Banco National Park, Côte d'Ivoire, a threatened West African rainforest. Salamandra 42: 41-51.

Barbour T, Loveridge A (1927) Some undescribed frogs and a new gecko from Liberia. Proceedings of the New England Zoölogical Club 10: 13-18

Barbour T, Loveridge A (1930) Reptiles and amphibians from Liberia. In: Strong RP (Ed.) The African Republic of Liberia and the Belgian Congo, Based on the Observations Made and Material Collected During the Harvard African Expedition 1926-1927, Vol. 2. Greenwood Press, New York, 769-786.

Barej MF, Schmitz A, Menegon M, Hillers A, Hinkel H, Böhme W, Rödel MO (2011) Dusted off - the African Amietophrynus superciliaris-species complex of giant toads. Zootaxa 2772: 1-32.

Barej MF, Schmitz A, Penner J, Doumbia J, Sandberger-Loua L, Hirschfeld M, Brede C, Emmrich M, Kouamé NG, Hillers A, Gonwouo NL, Nopper J, Adeba PJ, Bangoura MA, Gage C, Anderson G, Rödel MO (2015) Life in the spray zone - overlooked diversity in West African torrent-frogs (Anura, Odontobatrachidae, Odontobatrachus). Zoosystematics and Evolution 91: 115-149. https://doi. org/10.3897/zse.91.5127

Blackburn DC (2005) Cardioglossa liberiensis Barbour \& Loveridge 1927 is a junior synonym of Phrynobatrachus fraterculus (Chabanaud 1921). African Journal of Herpetology 54: 171-179. https:// doi.org/10.1080/21564574.2005.9635530

Blackburn DC (2010) A new squeaker frog (Arthroleptidae: Arthroleptis) from Bioko Island, Equatorial Guinea. Herpetologica 66: 320 334. https://doi.org/10.1655/09-039.1

Blackburn DC, Kosuch J, Schmitz A, Burger M, Wagner P, Gonwouo LN, Hillers A, Rödel MO (2008) A new species of Cardioglossa (Anura: Arthroleptidae) from the Upper Guinean forests of West Africa. Copeia 2008: 603-612. https://doi.org/10.1643/CH-06-233

Böhm M, Collen B, Baillie JEM, Chanson J, Cox N, Hammerson G, Hoffmann M, Livingstone SR, Ram M, Rhodin AGJ, Stuart SN, van Dijk PP, Young B, Afuang LE, Aghasyan A, Aguayo AG, Aguilar C, Ajtic R, Akarsu F, Alencar LRV, Allison A, Ananjeva N, Anderson S, Andrén C, Ariano-Sánchez D, Arredondo JC, Auliya M, Austin CC, Avci A, Baker PJ, Barreto-Lima AF, Barrio-Amorós CL, Basu D, Bates MF, Batistella A, Bauer A, Bennett D, Böhme 
W, Broadley D, Brown R, Burgess J, Captain A, Carreira S, Castaneda MR, Castro F, Catenazzi A, Cedeño-Vázquez JR, Chapple D, Cheylan M, Cisneros-Heredia DF, Cogalniceanu D, Cogger H, Corti C, Costa GC, Couper PJ, Courtney T, Crnobrnja-Isailovic J, Crochet PA, Crother B, Cruz F, Daltry J, Daniels RJR, Das I, de Silva A, Diesmos AC, Dirksen L, Doan TM, Dodd K, Doody JS, Dorcas ME, Duarte de Barros Filho J, Egan VT, El Mouden EH, Embert D, Espinoza RE, Fallabrino A, Feng X, Feng ZJ, Fitzgerald L, Flores-Villela O, França FGR, Frost D, Gadsden H, Gamble T, Ganesh SR, Garcia MA, García-Pérez JE, Gatus J, Gaulke M, Geniez P, Georges A, Gerlach J, Goldberg S, Gonzalez JCT, Gower DJ, Grant T, Greenbaum E, Grieco C, Guo P, Hamilton AM, Hammerson G, Hare K, Hedges B, Heideman N, Hilton-Taylor C, Hitchmough R, Hoffmann M, Hollingsworth B, Hutchinson M, Ineich I, Iverson J, Jaksic FM, Jenkins R, Joger U, Jose R, Kaska Y, Kaya U, Keogh JS, Köhler G, Kuchling G, Kumlutaş Y, Kwet A, La Marca E, Lamar W, Lane A, Lardner B, Latta C, Latta G, Lau M, Lavin P, Lawson D, LeBreton M, Lehr E, Limpus D, Lipczynski N, Livingstone S, Lobo AS, López-Luna MA, Luiselli L, Lukoschek V, Lundberg M, Lymberakis P, Macey R, Magnusson WE, Mahler DL, Malhotra A, Mariaux J, Maritz B, Marques OAV, Márquez R, Martins M, Masterson G, Mateo JA, Mathew R, Mathews N, Mayer G, McCranie JR, Measey GJ, Mendoza-Quijano F, Menegon M, Métrailler S, Milton DA, Montgomery C, Morato SAA, Mott T, Muñoz-Alonso A, Murphy J, Nguyen TQ, Nilson G, Nogueira C, Nunez H, Orlov N, Ota H, Ottenwalder J, Papenfuss T, Pasachnik S, Passos P, Pauwels OSG, Pérez-Buitrago N, Pérez-Mellado V, Pianka ER, Pleguezuelos J, Pollock C, Ponce-Campos P, Powell R, Pupin F, Quintero Díaz GE, Radder R, Ramer J, Rasmussen AR, Raxworthy C, Reynolds R, Richman N, Rico EL, Riservato E, Rivas G, Rocha PLB, Rödel MO, Rodríguez Schettino L, Roosenburg WM, Sadek R, Sanders K, Santos-Barrera G, Schleich HH, Schmidt BR, Schmitz A, Sharifi M, Shea G, Shi H, Shine R, Sindaco R, Slimani T, Somaweera R, Stafford P, Stuebing R, Sweet S, Sy E, Temple H, Tognielli MF, Tolley K, Tolson PJ, Tuniyev B, Tuniyev S, Üzüm N, van Buurt G, Van Sluys M, Velasco A, Vences M, Veselý M, Vinke S, Vinke T, Vogel G, Vogrin M, Vogt RC, Wearn OR, Werner YL, Whiting MJ, Wiewandt T, Wilkinson J, Wilson B, Wren S, Zamin T, Zhou K, Zug G (2013) The conservation status of the world's reptiles. Biological Conservation 157: 372-385. https://doi.org/10.1016/j.biocon.2012.07.015

Böhme W (2000) Diversity of a snake community in a Guinean rainforest (Reptilia, Serpentes). In: Rheinwald G (Ed.) Isolated vertebrate communities in the tropics: Proceedings of the $4^{\text {th }}$ International Symposium in Bonn. Bonner Zoologische Monographien 46: 69-78.

Böhme W, Schmitz A, Ziegler T (2000) A review of the West African skink genus Cophoscincopus Mertens (Reptilia: Scincidae: Lygosominae): resurrection of $C$. simulans (Vaillant, 1884) and description of a new species. Revue Suisse de Zoologie 107: 777-791. https://doi.org/10.5962/bhl.part.80148

Böhme W, Ziegler T (1997) A taxonomic review of the Varanus (Polydaedalus) niloticus (Linnaeus, 1766) species complex. The Herpetological Journal 7: 155-162.

Brochu CA (2007) Morphology, relationships, and biogeographical significance of an extinct horned crocodile (Crocodylia, Crocodylidae) from the Quaternary of Madagascar. Zoological Journal of the Linnean Society 150: 835-863. https://doi.org/10.1111/j.1096-3642.2007.00315.x
Chabanaud P (1921) Contribution à l'étude de la faune herpétologique de l'Afrique Occidentale. Bulletin du Comité d'Études Historiques et Scientifiques de l'Afrique Occidentale Française 1921: 445-472.

Chippaux JP (2001) Les serpents d'Afrique Occidentale et Centrale. Collection Faune et Flore tropicales 35. IRD éditions, Paris, 292 pp.

Collwell RK (2005) EstimateS Version 6.0b1. Statistical estimation of species richness and shared species from samples. http://viceroy. eeb.uconn.edu/estimates [Accessed on: 2019-1-16]

Dowell SA, Portik DM, de Buffrénil V, Ineich I, Greenbaum E, Kolokotronis SO, Hekkala ER (2015) Molecular data from contemporary and historical collections reveal a complex story of cryptic diversification in the Varanus (Polydaedalus) niloticus species group. Molecular Phylogenetics and Evolution 94: 591-604. https:// doi.org/10.1016/j.ympev.2015.10.004

Ernst R, Rödel MO (2005) Anthropogenically induced changes of predictability in tropical anuran assemblages. Ecology 86: 3111-3118. https://doi.org/10.1890/04-0800

Ernst R, Rödel MO (2006) Community assembly and structure of tropical leaf-litter anurans. Ecotropica 12: 113-129.

Ernst R, Rödel MO (2008) Patterns of community composition in two tropical tree frog assemblages: separating spatial structure and environmental effects in disturbed and undisturbed forests. Journal of Tropical Ecology 24: 111-120. https://doi.org/10.1017/ S0266467407004737

Euzet L, Combaz C, Knoepffler LP (1969) Parasites d'amphibiens de Côte d'Ivoire et du Liberia: Polystomatidae (Monogenea). Biologia Gabonica 3: 217-221.

Freedman AH, Thomassen HA, Buermann W, Smith TB (2010) Genomic signals of diversification along ecological gradients in a tropical lizard. Molecular Ecology 19: 3773-3788. https://doi.org/10.1111/ j.1365-294X.2010.04684.x

Frost DR (2018) Amphibian species of the World: an online reference. Version 6.0. http://research.amnh.org/herpetology/amphibia/index. html [Accessed on: 2018-8-14]

Glaw F, Vences M (2007) A Field Guide to the Amphibians and Reptiles of Madagascar. Vences \& Glaw Verlag, Köln, 496 pp.

Gramentz D (2005) Die Nilweichschildkröte Trionyx triunguis. Edition Chimaira, Frankfurt/M., 166 pp.

Guibé J (1959) Description d'un batracien nouveau de Côte d'Ivoire: Phrynobatrachus villiersi n. sp. Bulletin du Musée National d'Histoire Naturelle 31: 134-136.

Guibé J, Lamotte M (1954) Étude comparée de Rana (Ptychadena) longirostris Peters et $R$. (Pt.) aequiplicata Werner. Bulletin du Musée National d'Histoire Naturelle (2e Série) 26: 318-321.

Guibé J, Lamotte M (1957) Révision systématique des Ptychadena (Batraciens Anoures Ranidés) d'Afrique Occidentale. Bulletin de 1'Institute Fondamental d'Afrique Noire (Série A) 19: 937-1003.

Guibé J, Lamotte M (1958a) La réserve naturelle intégrale du Mont Nimba. XII. Batraciens (sauf Arthroleptis, Phrynobatrachus et Hyperolius). Mémoires de l'Institute Fondamental d'Afrique Noire 53: 241-273.

Guibé J, Lamotte M (1958b) Les Ptychadena (Batraciens, Ranidés) du Cameroun. Bulletin de l'Institute Fondamental d'Afrique Noire (Série A) 20(4): 1448-1463.

Guibé J, Lamotte M (1963) La réserve naturelle intégrale du Mont Nimba. XXVIII. Batraciens du genre Phrynobatrachus. Mémoires de l'Institute Fondamental d'Afrique Noire 66: 601-627. 
Hammer Ø, Harper DAT, Ryan PD (2001) PAST: Paleontological Statistics software package for education and data analysis. Paleontologica Electronica 4(1): 9 pp.

Henle K, Böhme W (2003) A new species of Hemidactylus (Squamata: Gekkonidae) from West Africa, and comments on species hitherto confused with H. muriceus. African Journal of Herpetology 52: 23-38. https://doi.org/10.1080/21564574.2003.9635474

Heyer WR, Donnelly MA, McDiarmid RW, Hayek LAC, Foster MS (1994) Measuring and Monitoring Biological Diversity, Standard Methods for Amphibians. Smithsonian Institution Press, Washington DC, $364 \mathrm{pp}$.

Hillers A (2013) Final report on the activities of the research unit, Across the River: A Transboundary Peace Park for Sierra Leone and Liberia, 2010-2013. Unpublished report, BirdLife and other contributors.

Hillers A, Boateng CO, Segniagbeto GH, Agyei AC, Rödel M-O (2009) Assessment of the amphibians in the forests of southern Ghana and western Togo. Zoosystematics and Evolution 85: 127-141. https:// doi.org/10.1002/zoos.200800019

Hillers A, Loua NS, Rödel MO (2008a) A preliminary assessment of the amphibians of the Fouta Djallon, Guinea, West Africa. Salamandra 44: 113-122.

Hillers A, Rödel MO (2007) The amphibians of three national forests in Liberia, West Africa. Salamandra 43: 1-10.

Hillers A, Veith M, Rödel MO (2008b) Effects of forest fragmentation and habitat degradation on West African leaf-litter frogs. Conservation Biology 22: 762-772. https://doi.org/10.1111/j.15231739.2008.00920.x

Hughes B (1979) Feeding habits of the frog Aubria subsigillata in Ghana. Bulletin de l'Institute Fondamental d'Afrique Noire (Série A) 41:654-663.

Inger RF, Menzies JI (1961) A new species of toad (Bufo) from Sierra Leone. Fieldiana Zoology 39: 589-594.

Johnston H (1906) Fauna: reptiles, amphibians, and fish. In: Liberia Vol. II. Hutchinson \& Co., London, 807-838.

Jongsma GFM, Barej MF, Barratt CD, Burger M, Conradie W, Ernst R, Greenbaum E, Hirschfeld M, Leaché AD, Penner J, Portik DM, Zassi-Boulou AG, Rödel MO, Blackburn DC (2018) Diversity and biogeography of frogs in the genus Amnirana (Anura: Ranidae) across sub-Saharan Africa. Molecular Phylogenetics and Evolution 120: 274-285. https://doi.org/10.1016/j.ympev.2017.12.006

Knoepffler LP (1976) Food habitats of Aubria subsigillata in Gabon. Zoologica Africana 11: 369-371. https://doi.org/10.1080/00445096 .1976 .11447542

Kouamé AM, Kouamé NG, Konan JCBYN, Adepo-Gourène AB, Rödel MO (2015) Contributions to the reproductive biology and behaviour of the dotted reed frog, Hyperolius guttulatus, in southern-central Ivory Coast, West Africa. Herpetology Notes 8: 633-641.

Kouamé NG, Tohé B, Assemian NE, Gourène G, Rödel MO (2008) Prey composition of two syntopic Phrynobatrachus species in the swamp forest of Banco National Park, Ivory Coast. Salamandra 44: 177-186.

Kouamé NG, Tohé B, Assemian NE, Gourène G, Rödel MO (2018) Spatio-temporal distribution of five species of West African leaf-litter frogs. Salamandra 54: 21-29.

Kpan TF, Adeba PJ, Kouamé NG, Koné I, Kouassi KP, Rödel MO (2014) The anuran fauna of a Volunteer Nature Reserve: the Tanoé-Ehy Swamp Forests, south-eastern Ivory Coast, West Africa. Zoosystematics and Evolution 90: 261-270. https://doi.org/10.3897/zse.90.8796
Kpan TF, Kouamé NG, Barej MF, Adeba PJ, Emmrich M, OforiBoateng C, Rödel MO (2018) A new Puddle Frog, genus Phrynobatrachus (Amphibia: Anura: Phrynobatrachidae), from the eastern part of the Upper Guinea biodiversity hotspot, West Africa. Zootaxa 4388: 221-237. https://doi.org/10.11646/zootaxa.4388.2.5

Lamotte M, Ohler A (1997) Redécouverte de syntypes de Rana bibroni Hallowell, 1845, désignation d'un lectotype et description d'une espèce nouvelle de Ptychadena (Amphibia, Anura). Zoosystema 19: 531-543.

Lamotte M, Ohler A (2000) Révision des espèces du groupe de Ptychadena stenocephala (Amphibia, Anura). Zoosystema 22: 569-583.

Lamotte M, Perret JL (1968) Révision du genre Conraua Nieden. Bulletin de l'Institute Fondamental d'Afrique Noire (Série A) 30: 1603-1644.

Lamotte M, Xavier F (1966) Étude comparée de deux espèces de Phrynobatrachus souvent confondues: Phr. plicatus Günther et Phr. auritus Boulenger. Bulletin de l'Institute Fondamental d'Afrique Noire (Série A) 28: 1605-1619.

Laurent RF (1958) Les rainettes du genre Hyperolius. Mémoires de 1'Institute Fondamental d'Afrique Noire 53: 275-299. [3 pls]

Leaché AD, Grummer JA, Miller M, Krishnan S, Fujita MK, Böhme W, Schmitz A, LeBreton M, Ineich I, Chirio L, Ofori-Boateng C, Eniang EA, Greenbaum E, Rödel MO, Wagner P (2017) Bayesian inference of species diffusion in the West African Agama agama species group (Reptilia, Agamidae). Systematics and Biodiversity 15: 192-203. https://doi.org/10.1080/14772000.2016.1238018

Leaché AD, Wagner P, Linkem CW, Böhme W, Papenfuss TJ, Chong RA, Lavin BR, Bauer AM, Nielsen SV, Greenbaum E, Rödel MO, Schmitz A, LeBreton M, Ineich I, Chirio L, Ofori-Boateng C, Eniang EA, Baha El Din S, Lemmon AR, Burbrink FT (2014) A hybrid phylogenetic-phylogenomic approach for species tree estimation in African Agama lizards with applications to biogeography, character evolution, and diversification. Molecular Phylogenetics and Evolution 79: 215-230. https://doi.org/10.1016/j.ympev.2014.06.013

Loveridge A (1941) Report on the Smithsonian-Firestone expedition collection of reptiles and amphibians from Liberia. Proceedings of the United States National Museum 91(3128): 113-140. https://doi. org/10.5479/si.00963801.91-3128.113

Mohneke M, Onadeko AB, Hirschfeld M, Rödel MO (2010) Dried or fried: amphibians in local and regional food markets in West Africa. TRAFFIC Bulletin 22: 117-128.

Myers N, Mittermeier RA, Mittermeier CG, Da Fonseca GAB, Kent J (2000) Biodiversity hotspots for conservation priorities. Nature 403: 853-858. https://doi:10.1038/35002501

Nago SGA, Grell O, Sinsin B, Rödel MO (2006) The amphibian fauna of the Pendjari National Park and surroundings, northern Benin. Salamandra 42: 93-108.

Nopper J, Gonwouo LN, Hillers A, Sandberger L, Ohler A, Rödel MO (2012) New data on the distribution and morphology of the West African squeaker frog Arthroleptis langeri Rödel, Doumbia, Johnson \& Hillers, 2009 (Amphibia: Anura: Arthroleptidae). Zootaxa 3170: 64-68.

Ofori-Boateng C, Leaché AD, Obeng-Kankam B, Kouamé NG, Hillers A, Rödel MO (2018) A new species of Puddle Frog, genus Phrynobatrachus (Amphibia: Anura: Phrynobatrachidae) from Ghana. Zootaxa 4374: 565-578. https://doi.org/10.11646/zootaxa.4388.2.5

Ohler A (1996) Systematics, morphometrics and biogeography of the genus Aubria (Ranidae, Pyxicephalinae). Alytes 13: 141-166.

Ohler A, Kazadi M (1990) Description d'une nouvelle espèce du genre Aubria Boulenger, 1917 (Amphibiens, Anoures) et rediscription du type d'Aubria subsigillata (A. Duméril, 1856). Alytes 8: 25-40. 
Onadeko AB, Rödel MO (2009) Anuran surveys in south-western Nigeria. Salamandra 45: 1-14.

Parker HW (1936) Amphibians from Liberia and the Gold Coast. Zoologische Mededelingen 19: 87-102.

Penner J, Adum GB, McElroy MT, Doherty-Bone T, Hirschfeld M, Sandberger L, Weldon C, Cunningham AA, Ohst T, Wombwell E, Portik DM, Reid D, Hillers A, Ofori-Boateng C, Oduro W, Plötner J, Ohler A, Leaché AD, Rödel MO (2013) West Africa - a safe haven for frogs? A sub-continental assessment of the chytrid fungus (Batrachochytrium dendrobatidis). PLoS ONE 8(2): e56236. https:// doi.org/10.1371/journal.pone.0056236

Penner J, Augustin M, Rödel MO (2019) Modelling the spatial baseline for amphibian conservation in West Africa. Acta Oecologica 94: 31-40. https://doi.org/10.1016/j.actao.2017.11.018

Penner J, Wegmann M, Hillers A, Schmidt M, Rödel MO (2011) A hotspot revisited - a biogeographical analysis of West African amphibians. Diversity and Distributions 17: 1077-1088. https://doi:10.1111/ j.1472-4642.2011.00801.x

Perret JL (1960) Etudes herpétologiques africaines II. Bulletin de la Société Neuchâteloise des Sciences Naturelles 83: 93-100 + 2 pls.

Perret JL (1966) Les amphibiens du Cameroun. Zoologische Jahrbücher (Systematik) 8: 289-464.

Perret JL (1983) Nouvelles données sur Hylarana occidentalis Perret (Amphibia, Ranidae). Bulletin de la Société Neuchâteloise des Sciences Naturelles 106: 109-113.

Perret JL (1994) Revision of the genus Aubria Boulenger 1917 (Amphibia Ranidae) with the description of a new species. Tropical Zoology 7: 255-269. https://doi.org/10.1080/03946975.1994.10539257

Perret JL (1997) Description de Ptychadena arnei n. sp. (Amphibia, Ranidae) une espèce méconnue d'Afrique Occidentale. Bulletin de la Société Neuchâteloise des Sciences Naturelles 120: 77-86.

Pickersgill M (2007) A redefinition of Afrixalus fulvovittatus (Cope, 1860) and Afrixalus vittiger (Peters, 1876) (Amphibia, Anura, Hyeroliidae). African Journal of Herpetology 56: 23-37. https://doi:10.1 080/21564574.2007.9635551

Poynton JC, Loader SP, Conradie W, Rödel MO, Liedtke HC (2016) Designation and description of a neotype of Sclerophrys maculata (Hallowell, 1854), and reinstatement of Sclerophrys pusilla (Mertens, 1937) (Amphibia: Anura: Bufonidae). Zootaxa 4098: 73-94. https://doi.org/10.11646/zootaxa.4098.1.3

Rödel MO (1998) A new Hyperolius species from Tai National Park, Ivory Coast (Anura: Hyperoliidae: Hyperoliinae). Revue française d'aquariologie herpétologie 25: 123-130.

Rödel MO (2000) Herpetofauna of West Africa, Vol. I: Amphibians of the West African savanna. Edition Chimaira, Frankfurt/M., 332 pp.

Rödel MO (2003) The amphibians of Mont Sangbé National Park, Ivory Coast. Salamandra 39: 91-110.

Rödel MO (2007) The identity of Hylambates hyloides Boulenger, 1906 and description of a new small species of Leptopelis from West Africa. Mitteilungen aus dem Museum für Naturkunde Berlin, Zoologische Reihe 83: 90-100. https://doi.org/10.1002/mmnz.200600031

Rödel MO, Agyei AC (2003) Amphibians of the Togo-Volta highlands, eastern Ghana. Salamandra 39: 207-234.

Rödel MO, Bangoura MA (2004) A conservation assessment of amphibians in the forêt Classée du Pic de Fon, Simandou Range, southeastern Republic of Guinea, with the description of a new Amnirana species (Amphibia Anura Ranidae). Tropical Zoology 17: 201-232. https://doi.org/10.1080/03946975.2004.10531206
Rödel MO, Bangoura MA, Böhme W (2004a) The amphibians of south-eastern Republic of Guinea (Amphibia: Gymnophiona, Anura). Herpetozoa 17: 99-118.

Rödel MO, Barej MF, Hillers A, Leaché AD, Kouamé NG, OforiBoateng C, Assemian NE, Tohé B, Penner J, Hirschfeld M, Doumbia J, Gonwouo LN, Nopper J, Brede C, Diaz R, Fujita MK, Gil M, Segniagbeto GH, Ernst R, Sandberger L (2012) The genus Astylosternus in the Upper Guinea rainforests, West Africa, with the description of a new species (Amphibia: Anura: Arthroleptidae). Zootaxa 3245: 1-29.

Rödel MO, Boateng CO, Penner J, Hillers A (2009b) A new cryptic Phrynobatrachus species (Amphibia: Anura: Phrynobatrachidae) from Ghana, West Africa. Zootaxa 1970: 52-63.

Rödel MO, Branch WR (2002) Herpetological survey of the Haute Dodo and Cavally forests, western Ivory Coast, Part I: Amphibians. Salamandra 38: 245-268.

Rödel MO, Brede C, Schiefenhövel P, Penner J, Sinsin B, Nago SGA (2007) The amphibians of the Lokoli Forest, a permanently inundated rainforest in the Dahomey Gap, Benin. Salamandra 43: 231-238.

Rödel MO, Doumbia J, Johnson AT, Hillers A (2009a) A new small Arthroleptis (Amphibia: Anura: Arthroleptidae) from the Liberian part of Mount Nimba, West Africa. Zootaxa 2302: 19-30.

Rödel MO, Emmrich M, Penner J, Schmitz A, Barej MF (2014) The taxonomic status of two West African Leptopelis species: L. macrotis Schiøtz, 1967 and L. spiritusnoctis Rödel, 2007 (Amphibia: Anura: Arthroleptidae). Zoosystematics and Evolution 90: 21-31. https:// doi: $10.3897 /$ zse. 90.7120

Rödel MO, Ernst R (2001) Redescription of the tadpole of Phlyctimantis boulengeri Perret, 1986, with preliminary comments on the biology of the species. Alytes 18: 178-186.

Rödel MO, Ernst R (2002a) A new reproductive mode for the genus Phrynobatrachus: Phrynobatrachus alticola has nonfeeding, nonhatching tadpoles. Journal of Herpetology 36: 121-125. https://doi. org/10.1670/0022-1511(2002)036[0121:ANRMFT]2.0.CO;2

Rödel MO, Ernst R (2002b) A new Phrynobatrachus from the Upper Guinean rain forest, West Africa, including a description of a new reproductive mode for the genus. Journal of Herpetology 36: 561-571. https:// doi.org/10.1670/0022-1511(2002)036[0561:ANPFTU]2.0.CO;2

Rödel MO, Ernst R (2004) Measuring and monitoring amphibian diversity in tropical forests. I. An evaluation of methods with recommendations for standardization. Ecotropica 10: 1-14.

Rödel MO, Gil M, Agyei AC, Leaché AD, Diaz RE, Fujita MK, Ernst R (2005a) The amphibians of the forested parts of south-western Ghana. Salamandra 41: 107-127.

Rödel MO, Grabow K (1995) Die Schildkröten und Krokodile des Comoé-Nationalparks, Elfenbeinküste (Reptilia: Testudines et Crocodylia). Faunistische Abhandlungen des Museums für Tierkunde Dresden 20: 133-144.

Rödel MO, Kosuch J, Kouamé NG, Ernst R, Veith M (2005b) Phrynobatrachus alticola Guibé \& Lamotte, 1961 is a junior synonym of Phrynobatrachus tokba (Chabanaud, 1921). African Journal of Herpetology 54: 93-98. https://doi.org/10.1080/21564574.2005.9 635522

Rödel MO, Krätz D, Ernst R (2002a) The tadpole of Ptychadena aequiplicata (Werner, 1898) with the description of a new reproductive mode for the genus (Amphibia, Anura, Ranidae). Alytes 20: 1-12.

Rödel MO, Mahsberg D (2000) Vorläufige Liste der Schlangen des TaïNationalparks / Elfenbeinküste und angrenzender Gebiete. Salamandra 36: $25-38$. 
Rödel MO, Ohler A, Hillers A (2010) A new extraordinary Phrynobatrachus (Amphibia: Anura: Phrynobatrachidae) from West Africa. Zoosystematics and Evolution 86: 257-261. https://doi.org/10.1002/ zoos. 201000008

Rödel MO, Range F, Seppänen JT, Noë R (2002b) Caviar in the rain forest: monkeys as frog spawn predators in Taï National Park, Ivory Coast. Journal of Tropical Ecology 18: 289-294. https:// doi:10.1017/S0266467402002195

Rödel MO, Rudolf VHW, Frohschammer S, Linsenmair KE (2004b) Life history of a West African tree-hole breeding frog, Phrynobatrachus guineensis Guibé \& Lamotte, 1961 (Amphibia: Anura: Petropedetidae). In: Lehtinen RM (Ed.) Ecology and evolution of phytotelm-breeding anurans. Miscellaneous Publications of the Museum of Zoology, University of Michigan 193: 31-44.

Rödel MO, Sandberger L, Doumbia J, Hillers A (2009c) Revalidation of Phrynobatrachus maculiventris Guibé \& Lamotte, 1958 and description of its aposematic coloured tadpole. African Journal of Herpetology 58: 15-27. https://doi.org/10.1080/21564574.2009.9635576

Rödel MO, Schorr G, Ernst R. (2001) Zur Biologie von Cardioglossa leucomystax (Boulenger, 1903), im Taï-Nationalpark, Elfenbeinküste. Salamandra 37: 239-260.

Roux-Esteve R (1969) Les serpents de la région de Lamto (Cöte d'Ivoire). Annales de l'Université d'Abidjan (Serie E) 2: 81-140.

Sandberger L, Hillers A, Doumbia J, Loua NS, Brede C, Rödel MO (2010) Rediscovery of the Liberian Nimba toad, Nimbaphrynoides liberiensis (Xavier, 1978) (Amphibia: Anura: Bufonidae), and reassessment of its taxonomic status. Zootaxa 2355: 56-68. https://doi. org/10.11646/zootaxa.2355.1.3

Schiøtz A (1967) The treefrogs (Rhacophoridae) of West Africa. Spolia zoologica Musei hauniensis 25: 1-346.

Schiøtz A (1968) On a collection of amphibia from Liberia and Guinea. Videnskabelige Meddelelser fra dansk Naturhistorik Forening 131: 105-108.

Schiøtz A (1999) Treefrogs of Africa. Edition Chimaira, Frankfurt/M., $350 \mathrm{pp}$.

Shirley MH, Vliet KA, Carr AN, Austin JD (2014) Rigorous approaches to species delimitation have significant implications for African crocodilian systematics and conservation. Proceedings of the Royal Society B 281: 20132483. https://doi.org/10.1098/rspb.2013.2483

SNCL (Society for the Conservation of Nature of Liberia) (2017) Report of Foya Forest rapid feasibility study for the establishment of Foya Nature Reserve in response to the expansion of protected area in Liberia. Unpublished report, Monrovia, Liberia.

Spawls S, Howell K, Drewes R, Ashe J (2004) A Field Guide to the Reptiles of East Africa. A. \& C. Black, London, 543 pp.

Stuart SN, Chanson JS, Cox NA, Young BE, Rodrigues ASL, Fischman DL, Waller RW (2004) Status and trends of amphibian declines and extinctions worldwide. Science 306: 1783-1786. https://doi. org/10.1126/science. 1103538

Stuart SN, Hoffmann M, Chanson JS, Cox NA, Berridge RJ, Ramani P, Young BE (2008) Threatened Amphibians of the World. Lynx Edicions, Barcelona, Spain, 758 pp.
Taylor EH (1968) The Caecilians of the World, a Taxonomic Review. University of Kansas Press, Lawrence, 848 pp.

Taylor EH, Weyer D (1958) Report on a collection of amphibians and reptiles from Harbel, Republic of Liberia. The University of Kansas Science Bulletin 38: 1191-1229. https://doi.org/10.5962/bhl. part. 10973

Trape JF (2015) Amphibiens et reptiles du Borkou - Ennedi - Tibesti et quelques observations d'autres vertébrés dans le nord du Tchad. Bulletin de la Société Herpétologique de France 154: 1-34.

Trape JF, Trape S, Chirio L (2012) Lézards crocodiles et tortues d'Afrique occidentale et du Sahara. IRD éditions, Marseille, 503 pp.

Uetz P (2018) The Reptile Database. http://www.reptile-database.org [Accessed on: 2018-9-14]

Vences M, Kosuch J, Rödel MO, Lötters S, Channing A, Glaw F, Böhme W (2004) Phylogeography of Ptychadena mascareniensis suggests transoceanic dispersal in a widespread African-Malagasy frog lineage. Journal of Biogeography 31: 593-601. https://doi. org/10.1046/j.1365-2699.2003.01031.x

Villiers A (1958) Tortues et crocodiles de l'Afrique noire Française. Initiations Africaines XV, Institut Français d'Afrieque Noire, Dakar, 354 pp.

Wagner P, Leaché AD, Fujita MK (2015) Description of four new West African forest geckos of the Hemidactylus fasciatus Gray, 1842 complex, revealed by coalescent species delimitation. Bonn Zoological Bulletin 63: 1-14.

Wells KD (2007) The Ecology and Behaviour of Amphibians. University of Chicago Press, Chicago, 1148 pp. https:/doi.org/10.7208/ chicago/9780226893334.001.0001

WCF (Wild Chimpanzee Foundation) \& FDA (Forestry Development Authority (2017) Baseline wildlife and anthropogenic survey in the proposed Krahn-Bassa Conservation Area. Unpublished report, Monrovia, Liberia.

Wüster W, Chirio L, Trape JF, Ineich I, Jackson K, Greenbaum E, Barron C, Kusamba C, Nagy ZT, Storey R, Hall C, Wuster CE, Barlow A, Broadley DG (2018) Integration of nuclear and mitochondrial gene sequences and morphology reveals unexpected diversity in the forest cobra (Naja melanoleuca) species complex in Central and West Africa (Serpentes: Elapidae). Zootaxa 4455: 68-98. https:// doi.org/10.11646/zootaxa.4455.1.3

Xavier F (1978) Une espèce nouvelle de Nectophrynoides (Anura, Bufonidae) des Monts Nimba, N. liberiensis n. sp. I - description de l'espèce. Bulletin de la Société Zoologique de France 103: 431-441.

Zimkus BM, Lawson LP, Barej MF, Barratt CD, Channing A, Dash KM, Dehling M, Du Preez L, Gehring PS, Greenbaum E, Gvoždík V, Harvey J, Kielgast J, Kusamba C, Nagy ZT, Pabijan M, Penner J, Rödel MO, Vences M, Lötters S (2017) Leapfrogging into new territory: How Mascarene ridged frogs diversified across Africa and Madagascar to maintain their ecological niche. Molecular Phylogenetics and Evolution 106: 254-269. https://doi.org/10.1016/j.ympev.2016.09.018

Zimkus BM, Rödel MO, Hillers A (2010) Complex patterns of continental speciation: Molecular phylogenetics and biogeography of sub-Saharan puddle frogs (Phrynobatrachus). Molecular Phylogenetics and Evolution 55: 883-900. https://doi.org/10.1016/j.ympev.2009.12.012 